Portland State University

PDXScholar

Civil and Environmental Engineering

Undergraduate Honors Theses

Spring 2016

\title{
Preliminary Design Guidelines for Poraver-Based Lightweight Concrete
}

Marlow Stanton

Portland State University

Follow this and additional works at: https://pdxscholar.library.pdx.edu/cengin_honorstheses

Part of the Civil and Environmental Engineering Commons

Let us know how access to this document benefits you.

\section{Recommended Citation}

Stanton, Marlow, "Preliminary Design Guidelines for Poraver-Based Lightweight Concrete" (2016). Civil and Environmental Engineering Undergraduate Honors Theses. 5.

https://doi.org/10.15760/honors.367

This Thesis is brought to you for free and open access. It has been accepted for inclusion in Civil and Environmental Engineering Undergraduate Honors Theses by an authorized administrator of PDXScholar. Please contact us if we can make this document more accessible: pdxscholar@pdx.edu. 


\title{
PRELIMINARY DESIGN GUIDELINES FOR PORAVER-BASED LIGHTWEIGHT CONCRETE
}

BY

\author{
MARLOW STANTON
}

A thesis submitted in partial fulfillment

of the requirement for the degree of

BACHELOR OF SCIENCE WITH DEPARTMENTAL HONORS

IN

CIVIL AND ENVIRONMENTAL ENGINEERING

Thesis Advisor:

Evan Kristof PE

Portland State University

(C)2016 


\section{ACKNOWLEDGEMENTS}

I would like to thank:

Evan Kristof, my faculty advisor for providing direction and advice for this project. Evan has been a remarkable teacher and I could not have completed this project without his mentorship.

Portland State University \& the Civil Engineering Department, for providing a great learning environment and access to excellent faculty.

Friends and the ASCE Concrete Canoe Team members for help mixing and testing the cylinders.

Lastly, my family for their support during my degree and specifically during this project. 


\section{Abstract}

This research project investigated lightweight Portland cement concrete batching procedures and developed guidelines for designing Poraver-based mixes. Lightweight concrete has a variety of applications, from structural fills to structural members. The study was completed in two stages: Stage 1 was a pilot study serving to confirm whether the ACI211.2-98 Volumetric Method was appropriate for Poraver-based lightweight concrete. Additionally, Stage 1 examined the range of outcomes possible with a large combination of test mixes and explored handling techniques for presoaked aggregate. Stage 2 focused on confirming the linear relationship of cement content and compressive strength through a large quantity of test cylinders. The test cylinders were produced and tested following ASTM standards. Stage 1 verified that Poraver-based lightweight concrete could be batched based on ACI211.2-98. Additionally a wide range of strengths and unit weights were achievable. However Stage 1 demonstrated the need for revised handing techniques for presoaked aggregate. Stage 2 confirmed that a linear relationship does exist between cement content and compressive strength of Poraver-based lightweight concrete. Stage 2 also showed that Poraver-based lightweight concrete could obtain very low unit weights $\left(<70 \mathrm{lb} / \mathrm{ft}^{3}\right)$, without the use of admixtures. The study overall demonstrated that Poraver-based lightweight concrete can produce structurally suitable concrete. The study also showed that there is potential for further research that could result in additional strength increases and weight reductions of Poraver-based lightweight concrete. 


\section{TABLE OF CONTENTS}

List of Figures …...............................................................................................................................

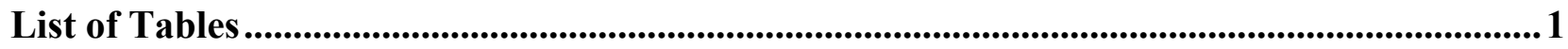

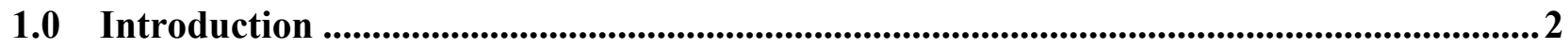

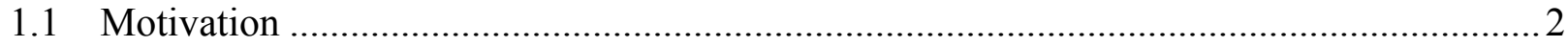

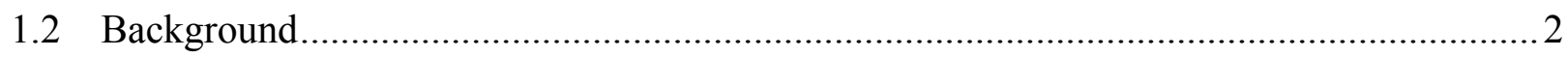

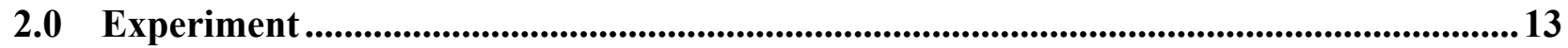

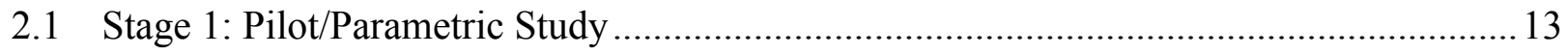

2.2 Stage 2: Targeted Study (68 Cylinders) …………………............................................. 19

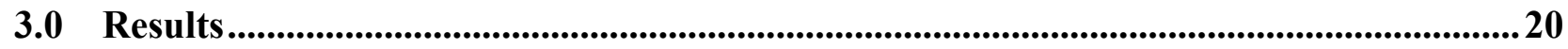

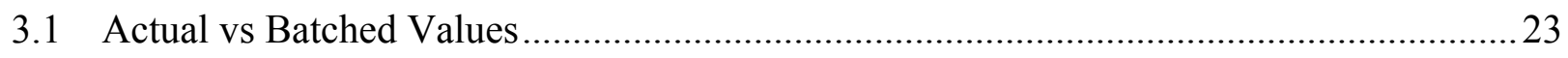

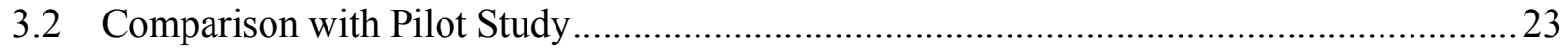

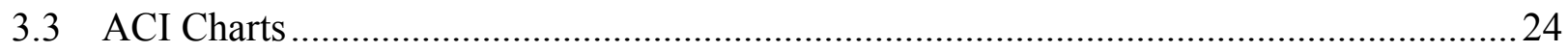

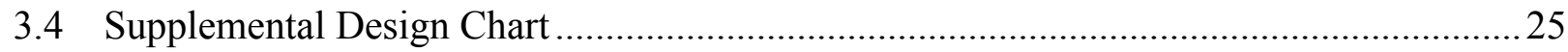

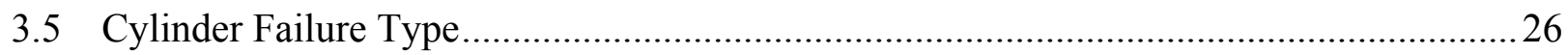

3.6 Strength, Aggregate Factor \& Unit Weight as a function of Cement Content ...................2 28

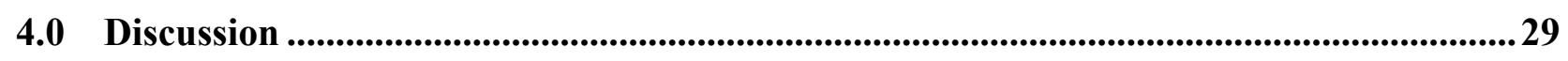

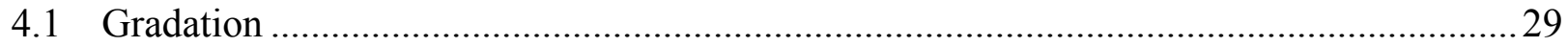

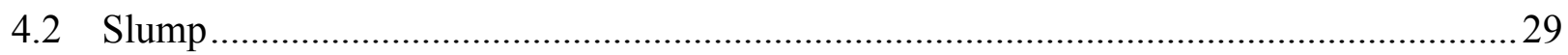

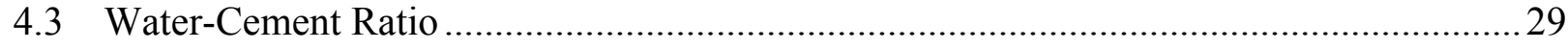

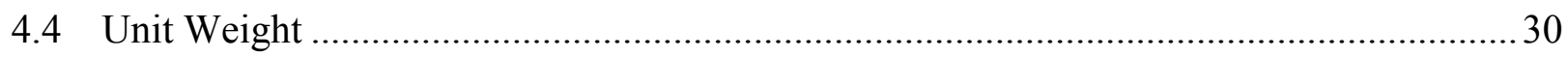

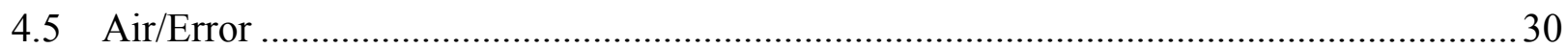

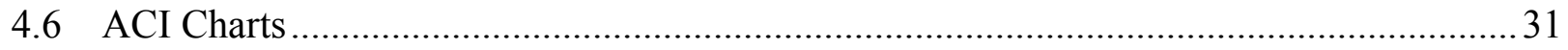

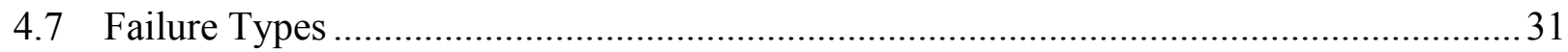

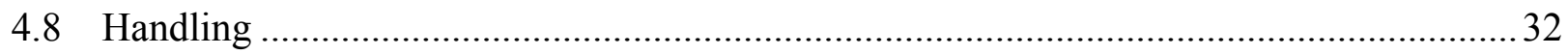

5.0 Conclusion ................................................................................................................................33

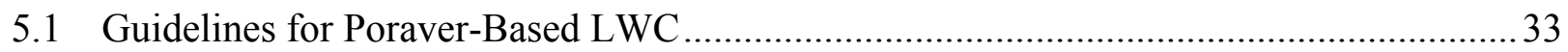

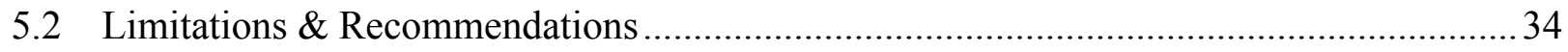

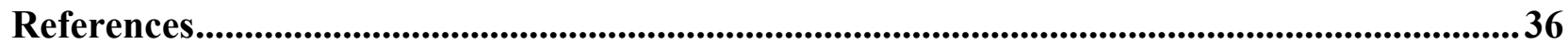




\section{APPENDICES}

A: RESEARCH DATA

B: ACI FIGURES 


\section{LIST OF FIGURES}

Figure 1: Optimum Combined Aggregate Gradation for Concrete ......................................... 7

Figure 2: Semi Log Blend Gradation Chart.............................................................................. 14

Figure 3: Pilot study design chart for Poraver based LWC ..................................................... 18

Figure 4: Pilot Study: Strength vs. Cement Content .................................................................. 18

Figure 5: Variation in Individual Cylinder Failure Stress ..........................................................2 22

Figure 6: Variation in Individual Cylinder Unit Weight ......................................................... 22

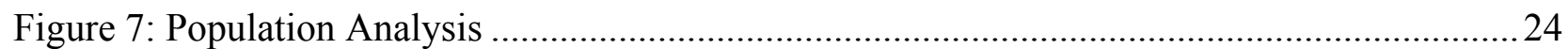

Figure 8: Design Chart for Uncombined Aggregates for Poraver Based Lightweight Poraver

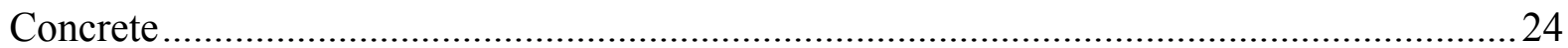

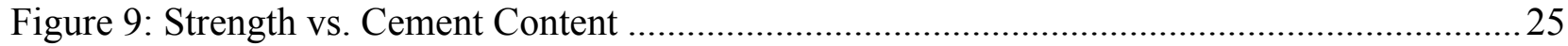

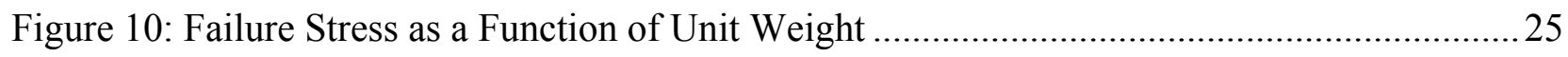

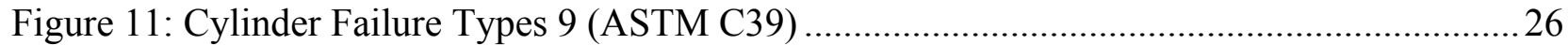

Figure 12: ASTM C39 Failure Type vs. Failure Stress ...........................................................2 27

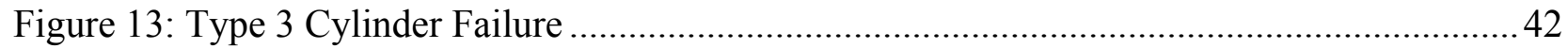

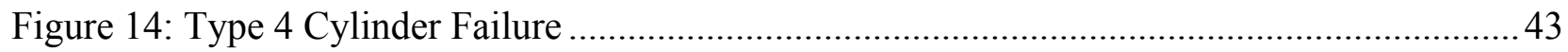

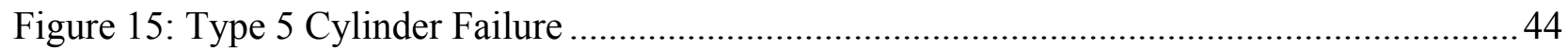

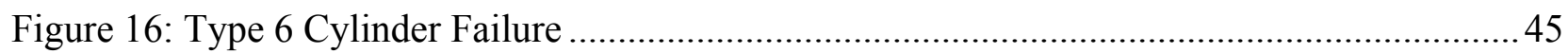

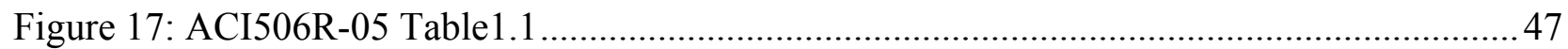

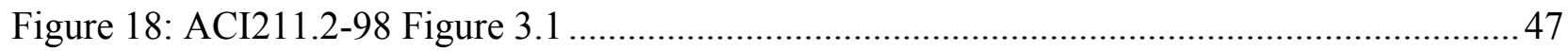

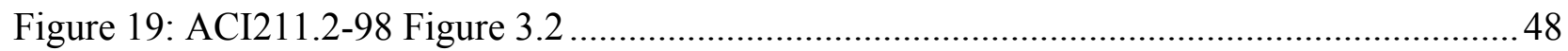

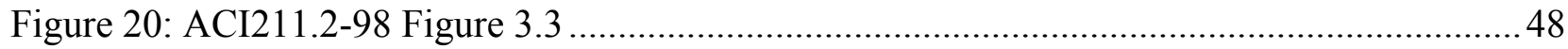

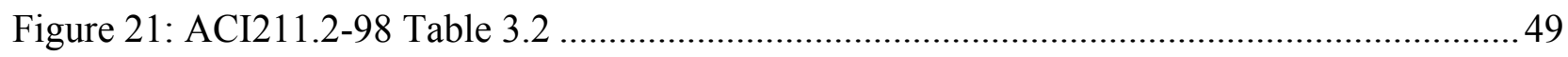

\section{LIST OF TABLES}

Table 1: Poraver Technical Data (Adapted from Poraver technical data sheet) ........................... 7

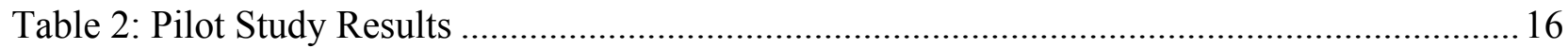

Table 3: Pilot Study Findings \& Recommendations ............................................................... 17

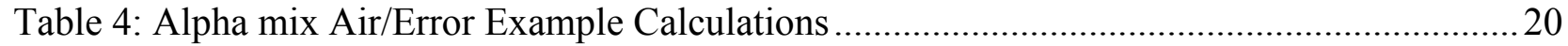

Table 5: Alpha \& Beta Results ......................................................................................... 21

Table 6: Poraver Batched Bulk Unit Weights ..........................................................................2 23

Table 7: Frequency of ASTM C39 Cylinder Failure Types …..................................................2 27

Table 8: Strength, Aggregate Factor \& Unit Weight as functions of Cement Content ..................28

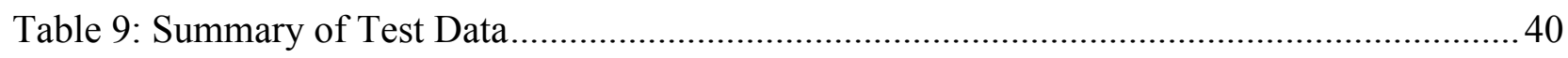

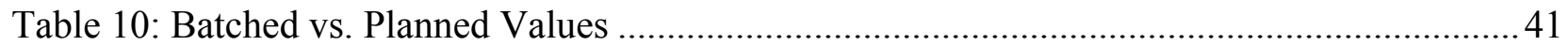




\subsection{INTRODUCTION}

The literature review focused on first examining concrete specifications and properties. It then reviewed applicable techniques for batching lightweight concrete.

\subsection{Motivation}

Lightweight concrete (LWC) is a fraction of total concrete use around the world. This is due to many factors, not limited to the large body of knowledge surrounding normal weight aggregates and the ready availability of normal weight components. However, LWC has the potential to help reduce the environmental impact of concrete construction. It can also help fulfill specific construction needs for buoyant concrete, high-strength structural fills, or even structural members.

This study will increase the body of knowledge in lightweight concrete with unit weights between 60-80 pcf, the LWC in this study will achieve these low unit weights through the use of a specific expanded glass aggregate called Poraver $®$. Poraver has been the aggregate of choice for the Portland State University (PSU) American Society of Civil Engineers (ASCE) Concrete Canoe Team for the last several years. It is extremely lightweight, with relatively high compressive strength. The team, in proportioning of Poraver-based LWC has built up anecdotal knowledge; however using a more defined set of guiding principles is required. Poraver is a very porous material and with common sizes between $0.1-4 \mathrm{~mm}$. The goal of this study is to develop guidelines for using Poraver effectively in LWC with consistent and predictable results.

\subsection{BACKGROUND}

"Portland cement concrete is the most widely used manufactured construction material in the world. "(Mamlouk, and Zaniewski 2011, 210).

Concrete is has strong scientific underpinnings, mostly in the design and production of cements. Experimentation is however still an active component of concrete design and construction, just like the original trial and error approach of initial concrete construction (Forty 2012, 39-40). There is additionally a large and growing body of knowledge in concrete design and construction, such as within the American Concrete Institute (ACI) \& Portland Cement Association (PCA).

There are many types of cements around the world that forms the basis of concrete, Portland cement being the most common. The cement is the glue or binder in concrete, holding the constituent parts together. Concrete made with Portland cement is often referred to as Portland Cement Concrete (PCC). It has the following fundamental ingredients: Portland cement, coarse and fine aggregates, water, air voids and often various admixtures (Mamlouk, and 
Zaniewski 2011, 210-211).

PCC is the most widely used construction material in the world, and therefore has a major impact on the environmental impact of building projects. Cement production emits a large amount of $\mathrm{CO}_{2}$ and requires a large amount of energy (Calkins 2009, 103). The primary method to reduce the environmental impact of concrete construction is to reduce the quantity of cement used. This is accomplished most commonly by substitution with natural cementitious materials.

When recycled materials can be substituted in place of both fine and coarse aggregates this can reduce the impact of aggregate extraction (Calkins 2009, 103). When using lightweight recycled aggregates, potential exists to reduce the environmental impact of PCC through: reduced transportation and fuel consumption, and limiting the impacts of aggregate extraction (Calkins 2009, IV).

Proportioning concrete mixes is a balancing act between many conflicting factors such as: strength, economy, workability, durability, appearance and density (ACI 211.1-91, 2). The ability to control these characteristics, or at least determine level of importance assigned to each characteristic, is fundamentally what makes concrete such a unique and valuable building material. Trial mixtures should always be utilized to confirm design specifications, and allow for design revision (ACI 211.1-91, 2).

According to Abrams Law (1918), all desirable qualities of concrete are influenced by the ratio of water to cement (by weight). This is the fundamental design consideration with PCC and is termed the "water-cement ratio" (or "water-cementitious materials ratio" if cementitious materials other than Portland cement are included in the mix). Fundamentally, a lower watercement ratio will provide a higher strength concrete. However, a minimum of $0.22-0.25 \mathrm{~kg}$ of water is required for comprehensive hydration of $1 \mathrm{~kg}$ of cement. Workability requirements will often dictate additional water above what is required for hydration. Excess water should be avoided to minimize the formation of capillary voids in the concrete, which create weaknesses from increased porosity and permeability (Mamlouk, and Zaniewski 2011, 220221).

Aggregate ${ }^{1}$ qualities are another important consideration for concrete mix design; in normal weight concrete they make up $60-70 \%$ of the weight of the constituent mix (Mamlouk, and Zaniewski 2011,166). In concrete mixtures, aggregates are used to fill volume and minimize the quantity of water and cement required (Mamlouk, and Zaniewski 2011, 253). Different aggregates can be used to give the concrete special characteristics such as reduced weight. The

${ }^{1}$ Stone, crushed rock, and sand 
use of recycled materials can be used to reduce costs or decrease the environmental burden of the concrete.

\subsubsection{Aggregates}

Aggregates are separated into two broad categories by size: Coarse aggregates (CA) and Fine aggregates (FA). Coarse aggregates are any particles retained on the $4.75 \mathrm{~mm}$ sieve (No.4). Fine aggregates are any particles passing the $4.75 \mathrm{~mm}$ sieve; the main measure of FA, is fineness modulus (FM). FM is a measure of the gradation of the FA, where a lower FM indicates a finer FA. Two other common properties are used to define aggregate characteristics: The "nominal maximum aggregate size" is one sieve larger than the first sieve to retain more than 10 percent of the aggregates. The "maximum aggregate size" is one sieve size larger than the nominal maximum aggregate size Mamlouk, and Zaniewski (2011).

According to Ozyildirim, generally decreasing the maximum aggregate size will result in increased compressive strength by decreasing the likelihood of internal weak planes. Additionally, the higher surface area associated with smaller particles allows for stronger bond with the cement paste. However, smaller particles will require an increase an overall quantity the cement paste (71-72).

Surface voids in the aggregate can take up water that is required for hydration. Aggregates can also bring free water to the mix; therefore the moisture content of the aggregates used must be known in order to determine the required water content of the mix. (Mamlouk, and Zaniewski 2011, 173-4).

Videla and Lopez found that there is a strong relationship between fresh mixed and air-dry densities of PCC. As the density of the mix increased, the difference between the fresh mixed and air-dried densities decreased. At all times, the fresh mixed densities were greater than air-dry densities, due to water loss during the curing process (285). Videla and Lopez also found that increasing the volumes of LWA had commensurate increases in water stored in the aggregate pores (285).

Compressive strength of the aggregates used in a mix is a limiting factor in design, where the mix cannot be stronger than the strength of the aggregates. Strength testing of aggregates is uncommon; however, estimates of PCC mix strength can be made if the aggregate strength is known (Mamlouk, and Zaniewski 2011, 178). 


\subsubsection{Lightweight aggregate properties (ACI 213R-14)(4-5)}

In addition to the properties important to normal weight concrete, critical LWA properties for proportioning are: particle shape and surface texture, and strength of aggregates (4). LWAs have considerably lower specific gravity than NWA. This is usually due to the cellular or porous nature of most LWA. LWA specific gravity is inversely proportional to aggregate size. In order to meet strength requirements, LWA densities are required to be at least $1 / 3-2 / 3$ that of normal weight aggregates. Otherwise additional cement will be required, negating the density advantages of the LWC (5). LWA bulk density has a range of $55-70 \mathrm{lb} / \mathrm{ft}^{3}$, compared to $100+\mathrm{lb} / \mathrm{ft}^{3}$ for NWA (5). The maximum compressive and tensile strengths of PCC are reached when the strength of the aggregates--rather than the paste strength--control. Generally lowering the water-cement ratio of a mix should increase the strength of the mix, if this no longer occurs, then the maximum strength has been met. An additional technique to raise the strength ceiling with $\mathrm{LWC}$ is to decrease the maximum size of the CA; this does have the effect of increasing the unit weight however. Compressive and tensile strengths do not increase at the same rate; compressive strength tends to increase far more rapidly than tensile strength (5-6).

In addition to unit weight, another key aspect of designing LWC mixtures is an understanding of the porosity, absorption, and degree of saturation of the LWA to be used. Because LWAs are commonly porous in nature this leads to high absorption rates. The fraction of the internal and external pores that are filled with water is the degree of saturation. The degree of saturation can be evaluated using a pychnometer. By utilizing a pychnometer, measurements can be taken at multiple absorption levels to determine the relative densities, allowing the use of the absolute volume method of proportioning (6). Gradation of LWA requires a volumetric distribution similar to NWA while having a greater mass of the aggregate pass through the finer sieves. This modification is required to account for the increased density with smaller particle sizes of LWA (6).

LWAs are required to absorb $5+\%$ by mass following the ASTM C127 absorption test. This is significant difference from normal weight aggregates, which commonly absorb less than $2 \%$, although stockpiled aggregates may have higher moisture contents. If higher moisture contents in NWA are found, that additional water is counted against added mixing water. One critical difference between NWA and LWA is that NWA moisture is mostly on the surface, whereas the LWA moisture is both on the surface and within the internal pore structure additional due to the inherent nature of LWA, any additional water is a higher percentage of the mass of the aggregate. This distinction is important for two reasons. First, the water absorbed into the interior pores is not always available for cement hydration and therefore should not be accounted for in the water- 
cement ratio. Second, this internally stored water is not available to increase slump or affect workability (7).

Due to the porous nature of LWA, it is preferential to prewet them in order for the added mixing water to be entirely available for cement hydration. The method and time required for adequate prewetting of the LWA will vary based on the differing individual properties of the LWA, such as porosity and initial water content. (9) Prewetting the LWA will add weight and therefore density to the concrete mix. Although adding weight and density to lightweight concrete can be undesirable, the additional water can be used for as internal curing. Internal curing occurs when the water absorbed by LWA is released into the cement paste and allows for additional hydration. The water is released when the pores in the cement paste are smaller than those of the aggregate. Internal curing is been shown to increase concrete performance by distributing the water more uniformly through the mix. Some benefits of internal curing are resistance to early cracking and enhanced durability. (36) Internal curing can lead to a density change from the wet mix density to the equilibrium dry density. (37) In order for LWA to be a useful internal curing reservoir, the LWA pores must be larger than those of the cement paste in order to facilitate movement from LWA to the cement paste. A number of studies have found that up to $98 \%$ of the internally stored water can be made available for curing; however, this can be as low as $60 \%$ depending on the aggregate (as cited by ACI 213R-14, (38) from Bentz et al. 2005; Radlinska et al. 2008). The usefulness of the LWA for internal curing will also depend on the absorption/desorption characteristics of the LWA under high relative humidity conditions (38). In a study by Lopez at al (2008), two high performance mixes were compared: the first with prewetted LWA; the second with air-dry LWA. After 24 hours, both had identical compressive strengths just above 10,000 psi. However, after one year the prewetted LWA mix recorded a compressive strength in excess of 12,500 psi whereas the air-dried mixture recorded just slightly above 11,000 psi (39).

\subsubsection{Combined Aggregate Gradation}

According to Kosmatka et al., there is an ideal combined gradation of fine and coarse aggregate for PCC (see Figure 1). This gradation follows a bell curve that is slightly biased toward a higher proportion of larger aggregate. The ideal gradation optimizes: effective water content, cement content, strength and minimizes particle interference (86). 


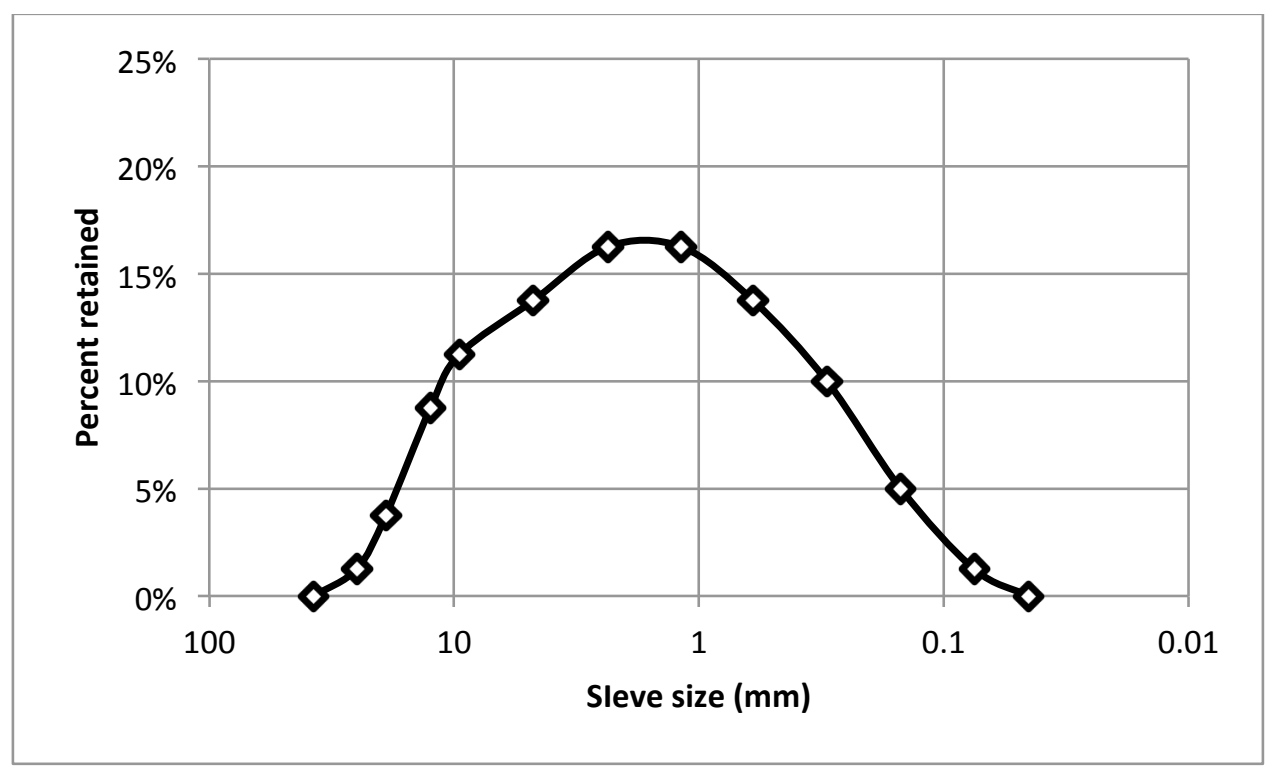

Figure 1: Optimum Combined Aggregate Gradation for Concrete

\subsubsection{Poraver $\AA$}

Poraver is available in five standard grain sizes, with bulk densities of $11-25 \mathrm{lb} / \mathrm{ft}^{3}$ and compressive strengths of 203-348 psi (see, Table 1). Poraver is currently used in a number of concrete applications such as lightweight masonry blocks, stucco, and lightweight precast structures. It is predominantly combined with other aggregates including: sand, gravel, Metapor ${ }^{\circledR}$, and expanded clay. It is also commonly combined with fillers such as fly ash and micro silica.

Table 1: Poraver Technical Data (Adapted from Poraver technical data sheet)

\begin{tabular}{|c|c|c|c|c|c|c|c|c|c|}
\hline & 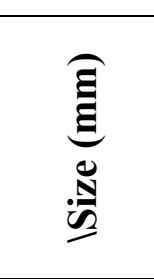 & 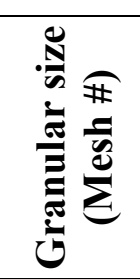 & 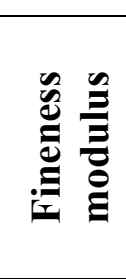 & & 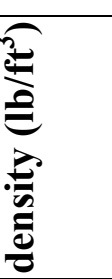 & & 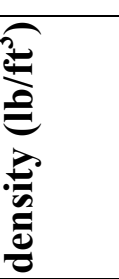 & 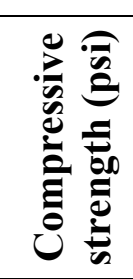 & 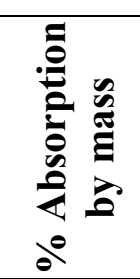 \\
\hline Standard & \multicolumn{3}{|c|}{ ASTM C136 } & \multicolumn{2}{|c|}{$\begin{array}{l}\text { ASTM } \\
\text { C9/C29M }\end{array}$} & \multicolumn{2}{|c|}{ ASTM C128 } & $\begin{array}{l}\text { EN } \\
13055- \\
1: 2002\end{array}$ & $\begin{array}{l}\text { ASTM } \\
\text { C128 }\end{array}$ \\
\hline \multirow{5}{*}{$\begin{array}{c}\text { Poraver }{ }^{\circledR} \\
\text { granular } \\
\text { sizes }\end{array}$} & $0.1-0.3$ & $140-50$ & 0.66 & 25 & $+/-3.8$ & 56.2 & $+/-8.4$ & 348 & 35 \\
\hline & $0.25-0.5$ & $60-35$ & 1.92 & 21.2 & $+/-3.2$ & 36.8 & $+/-5.6$ & 348 & 28 \\
\hline & $0.5-1$ & $35-18$ & 2.72 & 16.9 & $+/-3.0$ & 29.3 & $+/-4.4$ & 261 & 20 \\
\hline & $1-2$ & $18-10$ & 3.81 & 14.4 & $+/-2.1$ & 24.3 & $+/-3.6$ & 232 & 20 \\
\hline & $2-4$ & $10-5$ & 4.7 & 11.9 & $+/-1.8$ & 20 & $+/-3.0$ & 203 & 23 \\
\hline
\end{tabular}


Poraver-based concrete, with the addition of some NWA has been tested to a maximum compressive strength of $\sim 7000$ psi. However, without additional NWA, but still with the use of admixtures and fillers, the strength is limited to $\sim 2600$ psi with a unit weight of $60 \mathrm{lb} / \mathrm{ft}^{3}$.

Using small aggregates such as Poraver, which have very low fineness moduli can lead to less shrinkage cracking (Maruyama and Sugie 2014, 1). There is a strong correlation between the surface area of the aggregates batched and the shrinkage cracking of the finished concrete, where increased surface area reduces shrinkage (Maruyama and Sugie 2014, 1).

Poraver has a very high percent absorption of $20-30 \%$ by mass. This can add to the weight to the finished concrete, but also provides storage volume for water that can be used for internal curing. During mixing, some of this stored water can be converted to free water and vice versa (Martin et al. 2013, 22)

\subsubsection{Non-Lightweight Design Considerations:}

A number of non-lightweight concrete design codes were reviewed for their applicability batching Poraver-based LWC.

\subsubsection{Normal Weight Concrete Mix Design (ACI 211.1-91)}

The most common method for proportioning normal weight concrete is the absolute volume method (ACI 211.1-91, 7-13). Using this method, the constituent parts are allocated a proportion of the total volume, usually on a per-cubic-yard basis. The required characteristics of the finished concrete define the initial steps in the batching procedure. Design slump and aggregate size are functions of the placement, formwork requirements and strength. These factors combined with the desired air content will determine the amount of mixing water required.

The strength requirements will determine the water-cement ratio; the $\mathrm{W} / \mathrm{C}$ combined with the water content will give the cement content. The remaining volume is then filled with aggregates. The ratio of fine aggregates (FA) to coarse aggregates (CA) is a function of the size of the coarse aggregate and the fineness modulus of the fine aggregate. 


\subsubsection{Shotcrete ACI 506R-05}

Shotcrete is a form of concrete that is sprayed under pressure. There are two major forms of Shotcrete: wet mix and dry mix. Wet mix can provide compressive strengths up to $12,000 \mathrm{psi}$, where dry mix is limited to 7000 psi. Shotcrete is also classified based on the size of aggregates used. Coarse aggregate Shotcrete has a maximum particle size of $1 / 2$ in., whereas fine aggregate Shotcrete has a maximum particle size of. $3 / 8$ in. The corresponding gradations can be found in the Appendix. As with regular concrete, minimizing the water-cement ratio serves to increase the strength of the mix.

Proportioning Shotcrete utilizing the traditional concrete principals is often satisfactory, however some modifications are necessary to facilitate the spray application. Shotcrete has inherent differences that call for specific adaptations from traditional proportioning. Rebound is a significant concern with Shotcrete. It is the effect of particles being rebounded from the application surface, and being removed from the mix, these are often coarse aggregates but may also contain cement particles. With this factor in mind, mixes should be designed to a higher strength than required. Shotcrete proportioned using ACI 211.1-91 requires a total aggregate reduction, limiting the CA \& FA contents to $30 \%$ by weight of the mix.

\subsubsection{Lightweight Concrete Design}

Lightweight concrete requires specific codes and standards in order to maintain its effectiveness and function appropriately

\subsubsection{Structural Lightweight-Aggregate Concrete (ACI 213R-14)}

Lightweight concrete properties and performance depend on the aggregate used. Lightweight aggregates have internal pores that allow for lower relative density than regular aggregates. Pores in the surface of the aggregate, are relatively permeable and can fill with water within hours. Internal pores take more time to fill; potentially weeks, however some pores may never become saturated. (2-4). Some LWAs are produced from raw materials such as blast-furnace slag, clays, slates, shale and fly ash. Volcanic deposits can include highly porous and lightweight natural aggregates such as pumice and scoria (4-5). In general, structural LWC is specified to between 3000-5000 psi (8).

\subsubsection{Lightweight Concrete Specifications (ACI 211.2-98)}

The guidelines for structural lightweight aggregate concrete according to ACI 211.2-98 include three main parameters. Firstly the mix must be made using LWA that meets ASTM C330. Secondly the concrete must have an $\mathrm{f}^{\prime}{ }_{\mathrm{c}}$ in excess of 2500 psi when tested 
according to ASTM C330. Lastly the concrete must have an equilibrium unit weight no greater than $115 \mathrm{lb} / \mathrm{ft}^{3}$, according to ASTM C576 (2).

\subsubsection{LWC Proportioning (ACI 211.2-98)}

According to ACI 211.2-98 there are two principal methods to proportion a LWC mix. Method 1 is used when a combination of lightweight and normal weight aggregates are required. Method 2 can be used when either only LWA or a combination of normal and lightweight aggregate is proportioned (2-3). The key difference between the two methods is that method 1 is based on the specific gravity (mass) of the constituent parts, and method two is based on volume (4-11). When using method 2 , it is not possible to establish with accuracy the net water-cement ratio because of the difficulty in establishing whether the mixing water will be absorbed by the aggregate or not. Therefore when using method 2, proportioning is based on the cement air ratio (4).

Method 2: Volumetric Method (damp, loose volume) (11-15)

Step 1: Estimating the aggregate content including fine and coarse proportions The total volume of aggregate should be estimated using an aggregate factor of between 28 to $34 \mathrm{ft}^{3} / \mathrm{yd}^{3}$, with the fine aggregate being 40 to $60 \%$ of the total. The aggregate factor (AF) is based on the bulk volume of aggregate, which is determined after estimating the cement, air and water contents of the mix. It is the remaining volume, then converted to bulk volume. The volumes of aggregate should be computed on a damp and loose basis. Ideally baseline proportions should be obtained from the aggregate producer. The total volume of aggregate and the proportion of fine and coarse aggregate, depend both on the properties of the aggregate and the finished concrete desired. If sufficient information is not available from the aggregate supplier then multiple test batches should be produced, with varying cement contents, to gain an understanding how the aggregate will affect the finished concrete. The desired unit weight of the finished concrete can be used guide the aggregate proportions (11).

Step 2: Estimating cement content

There should be a direct relationship between cement content and strength for each aggregate type; however, this relationship will be different for each aggregate type. If information on this relationship is not available from the aggregate supplier, then Figure 18: ACI211.2-98 Figure 3 (See Appendix B) can be used as a starting point for cement content, based on the required compressive strength (11-12).

Step 3: Water content 
Water content can be obtained from ACI211.2-98 Table 3.2 (See Appendix B) page 5 , with additional water added, equal to that which the aggregate soaked for 48 hours in the laboratory (14)

Step 4: Initial trial batch weights

With initial cement content, water content and aggregate proportions determined, a sample trial mix can be created. From the known values the damp loose unit weight can be computed by dividing the total measured weight of the mix by its volume. After the trial batch has been mixed, the fresh unit weight can be computed by following ASTM C 138. The yield unit weight is determined by dividing the measured unit weight, by the fresh unit weight. From here, adjusted weights are calculated by dividing the trial batch weights by the yield unit weight, to obtain actual quantities required for the initial trial volume (12).

Because of the difficulty in developing strength guidelines based on the water cement ratio for a specific lightweight aggregate, it is practical to attempt to develop the design chart based on cement content. This is achieved by a series of trial batches proportioned on a cement content basis with the water content held constant. These trial batches are then tested in order to develop a "cement content strength relationship" for the series. This relationship should be linear with strength increasing as the cement content increases. A useful procedure for developing this relationship, when existing data is unavailable it to develop a graph like ACI211.298 Figure 3.2 (See Appendix B)

With workability, constant slump, similar air content and proper yield in mind, test batches are proportioned with different cement contents. The content of the combined coarse and fine aggregate is also varied and order to maintain the properties desired. On ACI211.2-98 Figure 3.2 (See Appendix B) movement from line $\mathrm{BB}$ up or down, to lines $\mathrm{AA}$ or $\mathrm{CC}$, with the same slope, can happen due to a variety of aggregate factors. For example line BB, would move down to line $\mathrm{CC}$ if the nominal maximum aggregate size was reduced due to a reduction in voids and vice versa (13). After an appropriate number of trial batches have been completed and tested, a second graph similar to ACI211.2-98 Figure 3.3 (See Appendix B) can be produced, showing a relationship between cement content and compressive strength (14). 


\subsubsection{Concrete testing (ACI 214R-11)}

In general, there are two main reasons for a variation in strength of tested concrete specimens: variations in the properties of the mixed concrete or variability in the testing of the concrete (3). Strength tests results must be based on the average of the test specimens and accordingly cannot be based on a single test specimen. Ideally, if full sized $6 \times 12$ " cylinders are used, a minimum of two specimens is required. Additionally if smaller than full sized cylinders are used, a minimum of three specimens is required. For most concrete strength tests below $10,000 \mathrm{psi}$, a normal distribution of results can be expected. If the strength of the specimens is controlled by aggregate failure, this may skew the distribution (4). As strengths increase, so does the peak of the curve (5). Ideally 30 or more tests should be completed to obtain statistically significant data and a useful standard deviation. A test result is the average of three cylinders. 


\subsection{EXPERIMENT}

A pilot parametric study (Stage 1) was conducted in accordance with applicable ASTM standards ${ }^{2}$ and ACI $\operatorname{codes}^{3}$ unless otherwise noted. The pilot study was then followed by a more in-depth analysis (Stage 2) based upon the findings of the pilot study. Stage 2 analyzed two mixes, with more significant quantities (34 cylinders each).

\subsection{Stage 1: Pilot/Parametric Study}

The initial pilot study had a limited scope, in order to refine the handling and proportioning characteristics for further research. The pilot study was limited to 15 cylinders, comprising two different gradations and five different cement contents.

\subsubsection{Goals and Hypothesis}

The Pilot study had three main goals, each discussed below.

\subsubsection{Test Procedures (Establish Handling Guidelines)}

Poraver is shipped to customers in various containers, all with claimed moisture content on delivery of $\leq 0.5 \%$ (Poraver). For simplification, this study assumed moisture content of $0 \%$. Due to high water absorption potential of Poraver, a method of presoaking the aggregate would help ensure that adequate mixing water is available for cement hydration.

\subsubsection{Confirm Linear Relationships \& Develop ACI Charts}

According to (ACI 211.2-98) it is desirable to develop a design chart for each type of LWC. The design chart should model ACI211.2-98 Figure 3.2 (Appendix B) and show the linear relationship between an aggregate factor and cement content, to aid in the design of test batches. After testing has occurred, it is then possible to create a chart of strength vs. cement content similar to ACI211.2-98 Figure 3.3 (Appendix B). The pilot study intends to confirm that these linear relationships exist for Poraver-based LWC and determine initial chart ranges.

\subsubsection{Establish Strength Range}

Poraver-based concrete has been shown to be capable of reaching an $\mathrm{f}_{\mathrm{c}}$ of $2600 \mathrm{psi}$ as the sole aggregate and up to 7000 psi combined with fillers and NWAs (Poraver). The

\footnotetext{
${ }^{2}$ ASTM C39 / C39M-16, C138 / C138M-16, C173 / C173M-16, C192 / C192M-16 \& C231 / C231M-14

${ }^{3}$ ACI211.2-98
} 
pilot study will verify the range of 28-day strengths possible using procedures and characteristics described in sections 2.1.2 \& 2.1.3.

\subsubsection{Design}

In order to guide the process of developing ACI211.2-98 Figure 3.2 \& ACI211.2-98 Figure 3.3, a combined fine and coarse gradation, developed using the Kosmatka et al (86) method was used. Gradation I uses all five of the common Poraver sizes and Gadation II, uses the smaller four sizes (see Figure 2). Five different trial batches were designed, three using Gradation I, and two using gradation II. Each trail batch had a different cement content to provide multiple points for the aggregate factor vs. cement content chart.

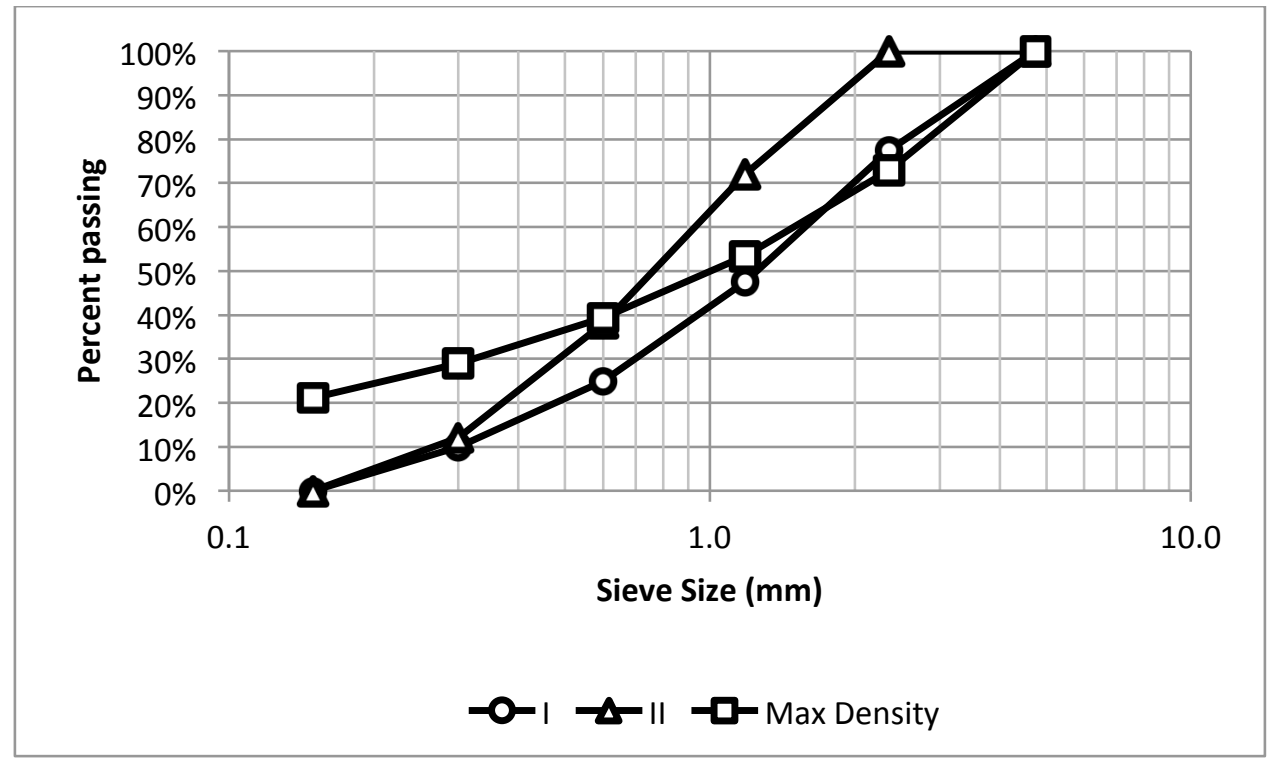

Figure 2: Semi-Log Aggregate Blend Gradation Chart

\subsubsection{Procedure}

Using the ACI211.2-98 volumetric method, five trial batches were developed that fit with the bulk density of the gradations developed. The trial batches were developed using with a target cement content, and then adding water using a guideline (minimum) value of 0.4 water-cement. An estimate of 3\% entrapped air was used. After the cement, water and air contents we're determined, a aggregate factor for the Poraver was determined. This process was followed for all five batches. The water content was used only as a starting point, as in accordance with the ACI211.2-98 it is this slump that should remain constant rather than the water content.

During the development of the pilot trial batches an error was made. The expected water to be absorbed in the Poraver was included in the volumetric calculations, rather than solely 
in the mass/weight calculations. This error lead to a $\sim 0.5$ lower aggregate factor than would have been determined.

An initial presoaking method was developed, which had unmeasured quantity's of Poraver in a 5 gal buckets. The buckets were then filled with water in order to attempt to submerge the Poraver for 24 hours (rather than 48 hours). The goal was to provide complete exposure and therefore allow 100\% saturation, to each grain of aggregate, in a simple and time efficient manner.

On batching day, the Poraver was drained through fine sieves to remove excess water. The required bulk volume Poraver was then obtained, it was then weighed to determine how much surface water was present. For simplicity it was assumed that the Poraver particles at this point were $100 \%$ saturated. Therefore the mass of surface water was equal to the total mass, less the mass of absorbed water and Poraver. For all five batches the surface water was far in excess of the expected mixing water and therefore no additional water was added. However, in order to maintain a consistent slump of 5 in $+/-1$ in, additional cement was added to mixes A, C \& E (see Table 2).

Table 2: Stage 1 Mix Design (Batch vs. Planned)

\begin{tabular}{|c|l|r|r|r|r|r|}
\hline \multicolumn{2}{|c|}{} & \multicolumn{1}{c|}{ A } & \multicolumn{1}{c|}{ B } & \multicolumn{1}{c|}{ C } & \multicolumn{1}{c|}{ D } & \multicolumn{1}{c|}{ E } \\
\cline { 3 - 7 } \multicolumn{2}{|c|}{} & Mass (lb) & Mass (lb) & Mass (lb) & \multicolumn{1}{c|}{ Mass (lb) } & \multicolumn{1}{c|}{ Mass (lb) } \\
\hline \multirow{3}{*}{$\begin{array}{c}\text { Cement } \\
\end{array}$} & Planned & 8.15 & 6.11 & 4.07 & 8.15 & 6.11 \\
\cline { 2 - 7 } & Actual & 12.56 & 6.11 & 8.15 & 8.15 & 14.95 \\
\cline { 2 - 7 } & Difference & $42.59 \%$ & $0.00 \%$ & $66.78 \%$ & $0.00 \%$ & $83.95 \%$ \\
\hline $\begin{array}{c}\text { Water- } \\
\text { hydration }\end{array}$ & Planned & 3.26 & 2.44 & 1.63 & 3.26 & 2.44 \\
\cline { 2 - 7 } & Actual & 8.01 & 7.21 & 6.42 & 5.91 & 8.52 \\
\cline { 2 - 7 } & Difference & $84.29 \%$ & $98.86 \%$ & $119.01 \%$ & $57.80 \%$ & $110.95 \%$ \\
\hline
\end{tabular}

Each batch was tested for unit weight following ASTM C138/C138M, and each individual test cylinder was also weighed. The cylinders were then left to cure for 28 days. At this time the cylinders were removed from the molds and weighed again. Each cylinder was then tested in a compression load frame according to ASTM C39/C39M.

\subsubsection{Results}

The test cylinders were difficult to remove from the cylinder molds. Upon removal from the molds, 11 out of 15 had portions of the base stuck to the inside of the mold. This resulted in a non-planar surface on the base of these cylinders. Regardless, all of the cylinders were then tested in these conditions without any repair. Gradation II mixes overall had greater strength than gradation I (see Table 3). Higher cement contents also had 
higher strengths. Gradation I mixes had a compressive strength from 710 - 2881 psi.

Gradation II mixes had a compressive strength from 2878 - 4432 psi.

Table 3: Pilot Study Results

\begin{tabular}{|c|c|c|c|c|c|c|}
\hline \multicolumn{2}{|c|}{ Trial Mix } & $\mathbf{A}$ & $\mathbf{B}$ & $\mathbf{C}$ & $\mathbf{D}$ & $\mathbf{E}$ \\
\hline Cement content & $\mathrm{lb} / \mathrm{yd}^{3}$ & 941 & 488 & 614 & 733 & 1011 \\
\hline Plastic unit Weight & $\mathrm{lb} / \mathbf{f t}^{3}$ & 73.3 & 59.1 & 61.4 & 68.4 & 77.2 \\
\hline Measured Unit weight & $\mathbf{l b} / \mathbf{f t}^{3}$ & 73.5 & 59.3 & 54.1 & 69.0 & 80.6 \\
\hline Difference in unit WT & $\%$ & 0.26 & 0.30 & -11.98 & 0.99 & 4.31 \\
\hline Yield & & 1.00 & 1.00 & 1.14 & 0.99 & 0.96 \\
\hline Oven Dry Unit WT & $\mathrm{lb} / \mathbf{f t}^{3}$ & 55.0 & 37.7 & 44.1 & 50.0 & 59.8 \\
\hline Plastic - oven & $\mathrm{lb} / \mathbf{f t}^{3}$ & 18.3 & 21.5 & 17.3 & 18.4 & 17.4 \\
\hline $\begin{array}{l}\text { Retained moisture factor } \\
\text { per ASTM C567 }\end{array}$ & $\mathbf{l b} / \mathbf{f t}^{3}$ & 13.7 & 16.1 & 13.0 & 13.8 & 13.1 \\
\hline Approx. air dry WT & $\mathbf{l b} / \mathbf{f t}^{3}$ & 68.7 & 53.8 & 57.1 & 63.8 & 72.9 \\
\hline Dry loose uncombined & $\mathrm{lb} / \mathbf{f t}^{3}$ & 17.8 & 17.8 & 17.8 & 18.3 & 18.3 \\
\hline Aggregate factor & $\mathrm{ft}^{3} / \mathrm{yd}^{3}$ & 20.0 & 24.2 & 25.5 & 25.7 & 22.0 \\
\hline W/C (excluding. abs. water) & & 0.64 & 1.18 & 0.79 & 0.73 & 0.57 \\
\hline Total W/C & & 0.73 & 1.39 & 0.96 & 0.81 & 0.64 \\
\hline Slump & in. & 6.00 & 5.50 & 5.50 & 5.50 & 5.50 \\
\hline \multirow{3}{*}{ New batch list } & $\mathrm{lb} / \mathrm{yd}^{3}$ & 1979 & 1596 & 1659 & 1846 & 2085 \\
\hline & $\mathbf{l b} / \mathbf{f t}^{3}$ & 73.3 & 59.1 & 61.4 & 68.4 & 77.2 \\
\hline & $\mathrm{ft}^{3} / \mathrm{yd}^{3}$ & 23.4 & 22.6 & 22.4 & 26.0 & 26.1 \\
\hline Air/error & $\mathrm{ft}^{3} / \mathrm{yd}^{3}$ & 3.60 & 4.36 & 4.60 & 1.00 & 0.85 \\
\hline Air/error & $\%$ & 0.13 & 0.16 & 0.17 & 0.04 & 0.03 \\
\hline Batch plastic unit wt & $\mathrm{lb} / \mathbf{f t}^{3}$ & 73.3 & 59.1 & 61.4 & 68.4 & 77.2 \\
\hline Unit weight & $\mathrm{lb} / \mathbf{f t}^{3}$ & 72.6 & 53.9 & 53.4 & 68.5 & 79.6 \\
\hline Failure Stress (f'c) & psi & 2881 & 710 & 978 & 2878 & 4432 \\
\hline
\end{tabular}




\subsubsection{Handling Recommendations}

Key shortcomings of the Stage 1 and recommendations for Stage 2 of this study were developed (see Table 4).

Table 4: Pilot Study Findings \& Recommendations

\begin{tabular}{|c|c|c|}
\hline & Findings & Recommendations \\
\hline \multirow[t]{4}{*}{ Batching } & $\begin{array}{l}\text { Measuring the volume of 'wet' Poraver was difficult } \\
\text { and the measuring equipment was only delineated in } \\
100 \mathrm{ml} \text { increments. }\end{array}$ & \multirow{2}{*}{$\begin{array}{l}\text { B1: Measure required } \\
\text { volume of Poraver dry, and } \\
\text { then combine with a } \\
\text { measured amount of water } \\
\text { to soak } 24 \mathrm{hrs} \text {. With this } \\
\text { change, no measurements of } \\
\text { 'wet' Poraver are required. } \\
\text { Use measuring equipment } \\
\text { with increased precision }\end{array}$} \\
\hline & $\begin{array}{l}\text { For the larger Poraver sizes, the volume } \\
\text { measurements seem reasonable. However for the } \\
\text { finer sizes }(0.1-0.3 \mathrm{~mm} \& 0.25-0.5 \mathrm{~mm}) \text { it is difficult } \\
\text { to discern if the volume measurement is based on } \\
\text { the Poraver or the water or both, this likely lead to } \\
\text { inaccuracies in the volumetric measurements. }\end{array}$ & \\
\hline & $\begin{array}{l}\text { Poraver soaked in water can have excessive surface } \\
\text { water, which leads to excessive water content in the } \\
\text { concrete mix. This excess water content negates the } \\
\text { need for additional mixing water and often requires } \\
\text { additional cement to meet slump requirements. }\end{array}$ & $\begin{array}{l}\text { B2: Soaking water should } \\
\text { be in excess of absorption } \\
\text { requirements, but below } \\
\text { estimating total water } \\
\text { requirements }\end{array}$ \\
\hline & $\begin{array}{l}\text { Absorbed water was included in volumetric unity for } \\
\text { the mix design, when it is locked inside of the } \\
\text { Poraver and should not be included in volume } \\
\text { calculations, but should be included in mass/weight } \\
\text { calculations. }\end{array}$ & $\begin{array}{l}\text { B3: Exclude absorbed water } \\
\text { from unity volumetric } \\
\text { calculations, continue to } \\
\text { include in mass } \\
\text { calculations. }\end{array}$ \\
\hline \multirow[t]{3}{*}{ Testing } & $\begin{array}{l}\text { Upon removal of the test cylinder from their molds, } \\
11 / 15 \text { specimens broke at the base as portions } \\
(\sim 1 / 8 \text { th in. over } 3 / 4 \text { of the surface) of the cylinder } \\
\text { remained in the mold. }\end{array}$ & $\begin{array}{l}\text { T1: Apply form release } \\
\text { agent to molds prior to } \\
\text { filling with test mixes. }\end{array}$ \\
\hline & $\begin{array}{l}\text { A small number of test specimens had uneven or } \\
\text { angled top surfaces. }\end{array}$ & $\begin{array}{l}\text { T2: Increase QA/QC of test } \\
\text { specimen production. } \\
\text { Develop method of } \\
\text { smoothing/leveling } \\
\text { cylinders after pouring. }\end{array}$ \\
\hline & $\begin{array}{l}\text { Air testing equipment available is not suitable for } \\
\text { testing LWC }\end{array}$ & $\begin{array}{l}\text { T3: Obtain volumetric air } \\
\text { meter }\end{array}$ \\
\hline
\end{tabular}




\subsubsection{ACI charts}

Design charts for both gradations were developed (see Figure 3). The data predominately fit with the ACI211.2-98 guidelines, with finer gradations requiring a higher aggregate factor. However the line for gradation 2 should be below that of gradation 1, this is not the case and is likely due to the excessive mixing water affecting the results. Additional test results would enable a more refined chart, however with the limited data points there is consistency between the two different gradations.

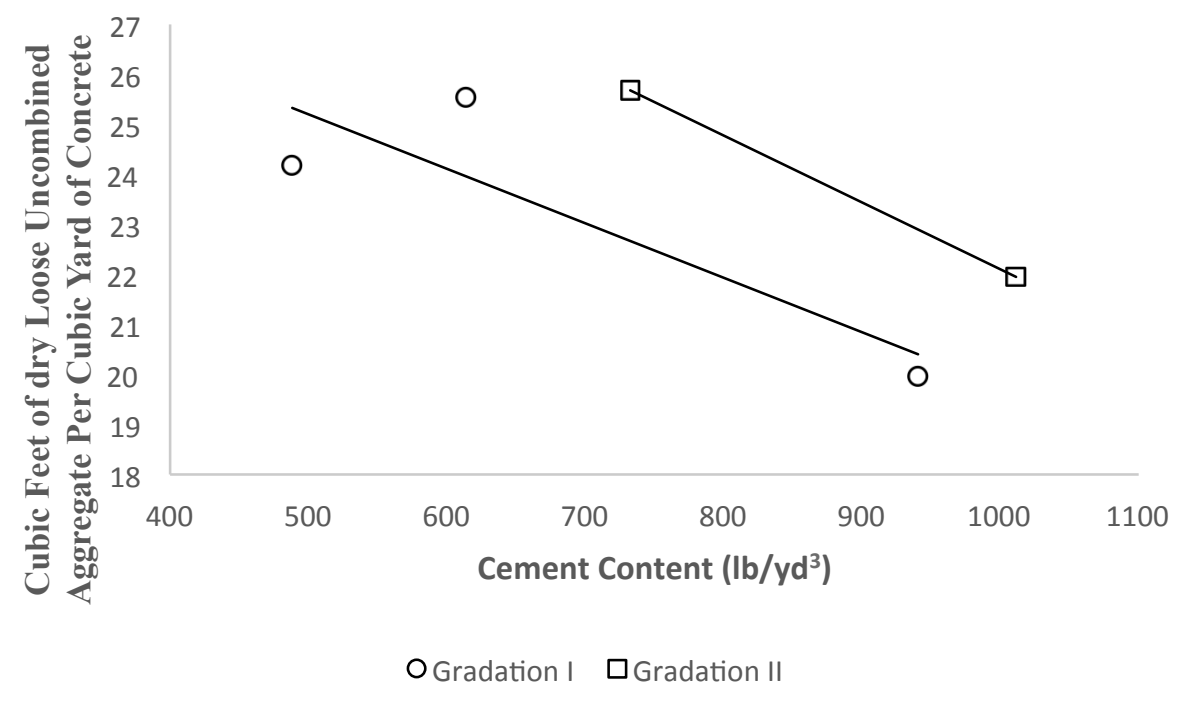

Figure 3: Pilot study design chart for Poraver-based LWC

The strength vs. cement content was also consistent with the ACI211.1-98 example. Gradation (II) had higher strengths than gradation I (see Figure 4).

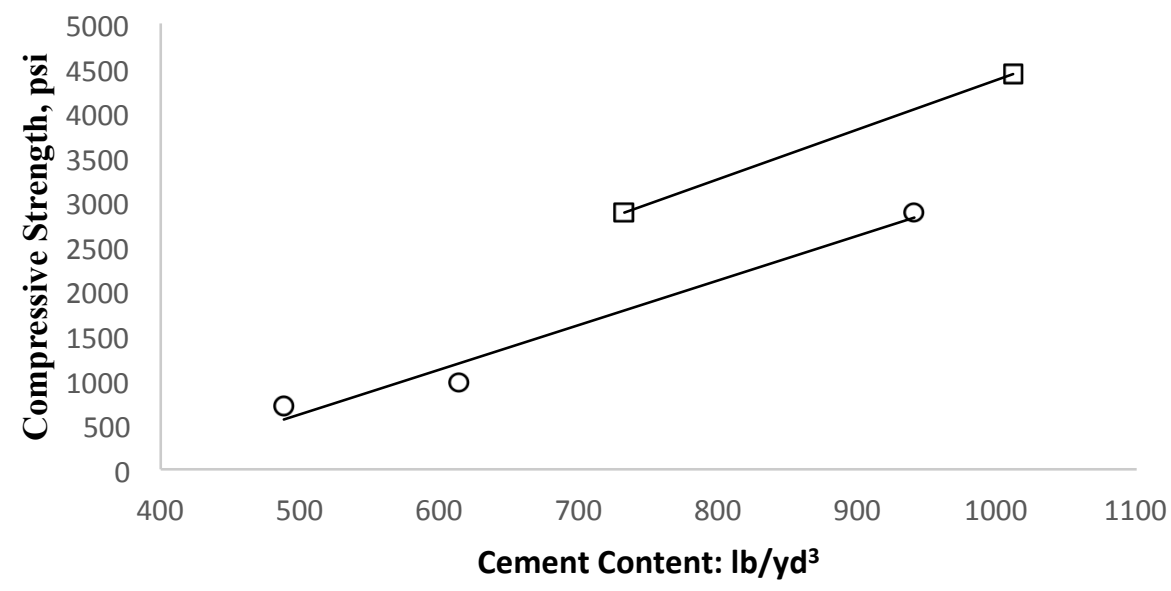

O Gradation I $\square$ Gradation II

Figure 4: Pilot Study - Strength vs. Cement Content 


\subsection{Stage 2: TARgeted StUdy (68 Cylinders)}

Stage 2 of the study was limited to a single gradation, with two different cement contents. Each trial mixture was batched and produced 34 test cylinders, for a total of 68 cylinders

\subsubsection{Goals and Hypothesis}

For stage 2 of the study, similar goals to the pilot study were developed to build on the results and findings of the pilot.

\subsubsection{Test Procedures (Establish Handling Guidelines)}

For stage 2 of the study of the project, the goal was to incorporate the handling recommendations from the pilot study. After incorporating the changes, new and unforeseen issues will undoubtedly arise, leading to additional recommendations for future Poraver batching.

\subsubsection{68 Cylinders}

For stage 2 of the study, each of the two test batches was created to produce 34 individual cylinders each.

\subsubsection{Develop/Refine ACI Charts}

For stage 2 of the study, ACI 211.2-98 charts 3.3 .4 a \& b, were developed using the new data

\subsubsection{Design}

For stage 2 of the study, gradation I was chosen as it is most representative of what the current PSU concrete canoe team is using. Pilot study mixes A \& B were modified based on the actual batched values to create new trial batches $\alpha \& \beta$, $\alpha$ was adjusted to have cement contents of $1000 \mathrm{lb} / \mathrm{yd}^{3}$, and $\beta 600 \mathrm{lb} / \mathrm{yd}^{3}$.

\subsubsection{Procedure}

Similar to the pilot study the ACI211.2-98 volumetric method was followed. With the findings of the pilot study, a new method for presoaking and measuring the Poraver was developed. Each size of Poraver, for each batch was measured dry and placed in individual buckets labeled $\alpha \& \beta$. Each bucket was then filled with the expected amount of absorbed water for each Poraver size. Of the estimated mixing water, $90 \%$ was then divided proportionally into the buckets of Poraver to help achieve contact with all the surface pores of the aggregate. The Poraver was then left 24 hours before mixing. 


\subsection{RESULTS}

For Stage 2 of the project $1.77 \mathrm{ft}^{3}$ of each Alpha and Beta mixtures were batched. This design volume was chosen to produce 30 cylinders of each mix, with allowance for spillage and waste. This design volume produced enough usable concrete to fill 34 cylinders of each mix. Despite following the handling recommendations in Section 2.1.4.1, using a form release agent (motor oil) a number of cylinders came out of the molds with portions stuck to the bottom of the molds. Each cylinder that came out less than intact was then cut on a miter saw to leave a smooth, flat and perpendicular surface. The Alpha mix failed at an average stress of 3594 psi, and Beta 1503 psi (see Table 6). Air content was unable to be measured accurately due to a lack of an available appropriate volumetric air tester. The Air/Error values were calculated using the properties of equality (see Table 5). The known mass values for cement and water were converted to volume, and then combined with the known volume of Poraver. When these values are summed the unit volume was determined to be missing 0.95 (Alpha) \& $1.44 \mathrm{ft}^{3} / \mathrm{yd}^{3}$ (Beta) equivalent to $3.5 \& 5.3 \%$ respectively (see Table 6). These values encompass both the entrapped air and include the sum of the error in all of the measurements. The variation between the designed (plastic) and measured unit weights was between $0.2 \% \& 2 \%$.

Table 5: Alpha mix Air/Error Example Calculations

\begin{tabular}{|c|c|c|c|}
\hline & 1 & 2 & 3 \\
\hline & Measured values & & \\
\hline & $\mathrm{lb} / \mathrm{yd}^{3}$ & $\mathrm{ft}^{3} / \mathrm{yd}^{3}$ & $\%$ \\
\hline Poraver & 378.2 & 12.67 & $47 \%$ \\
\hline Absorbed Water & 80.31 & - & - \\
\hline Free Water & 486.3 & 7.790 & $29 \%$ \\
\hline Cement & 1098.0 & 5.590 & $21 \%$ \\
\hline Sub Total & 2042.8 & 26.1 & $96 \%$ \\
\hline Air/Error & - & 0.95 & $3.52 \%$ \\
\hline Total & 2042.8 & 27.0 & $100 \%$ \\
\hline
\end{tabular}


Table 6: Alpha \& Beta Results

\begin{tabular}{|c|c|c|c|}
\hline & & Alpha & Beta \\
\hline Cement Content & $\mathrm{lb} / \mathrm{yd}^{3}$ & 1098 & 521 \\
\hline Plastic Unit Weight & $\mathbf{l b} / \mathbf{f t}^{3}$ & 76 & 57 \\
\hline Measured Unit Weight & $\mathbf{I b} / \mathbf{f t}^{3}$ & 77 & 57 \\
\hline Difference in Unit Weight & & $1.99 \%$ & $-0.20 \%$ \\
\hline Yield & & 0.98 & 1.00 \\
\hline Oven Dry Unit Weight & $\mathbf{l b} / \mathbf{f t}^{3}$ & 62.8 & 41.9 \\
\hline Plastic - Oven & $\mathbf{I b} / \mathbf{f t}^{3}$ & 12.9 & 14.9 \\
\hline $\begin{array}{l}\text { Retained Moisture Factor per } \\
\text { ASTM C567 }\end{array}$ & $\mathbf{l b} / \mathbf{f t}^{3}$ & 9.6 & 11.2 \\
\hline Approximate Air Dry Weight & $\mathbf{I b} / \mathbf{f t}^{3}$ & 72.5 & 53.0 \\
\hline Dry loose Uncombined & $\mathbf{l b} / \mathbf{f t}^{3}$ & 13.5 & 13.6 \\
\hline Aggregate Factor & $\mathrm{ft}^{3} / y \mathrm{~d}^{3}$ & 27.9 & 37.3 \\
\hline $\begin{array}{l}\text { Water/Cement (Excluding } \\
\text { Absorbed Water) }\end{array}$ & & 0.44 & 0.76 \\
\hline Total Water/Cement & & 0.52 & 0.97 \\
\hline Slump & in. & 5.25 & 6.00 \\
\hline \multirow{2}{*}{ New Batch List } & $\mathrm{lb} / \mathrm{yd}^{3}$ & 2043 & 1532 \\
\hline & $\mathrm{ft}^{3} / \mathrm{yd}^{3}$ & 26.05 & 25.56 \\
\hline \multirow{2}{*}{ Air/Error } & $\mathrm{ft}^{3} / \mathrm{yd}^{3}$ & 0.95 & 1.44 \\
\hline & $\%$ & $3.5 \%$ & $5.3 \%$ \\
\hline Batch Plastic Unit Weight & $\mathrm{Ib} / \mathbf{f t}^{3}$ & 75.7 & 56.7 \\
\hline
\end{tabular}

In order to determine if any cylinders were outliers, comparisons were made between each set of cylinders. Comparisons of both unit weight and failure stress were completed; Alpha mix had slightly more variation in failure stress than Beta mix (see Figure 5). 


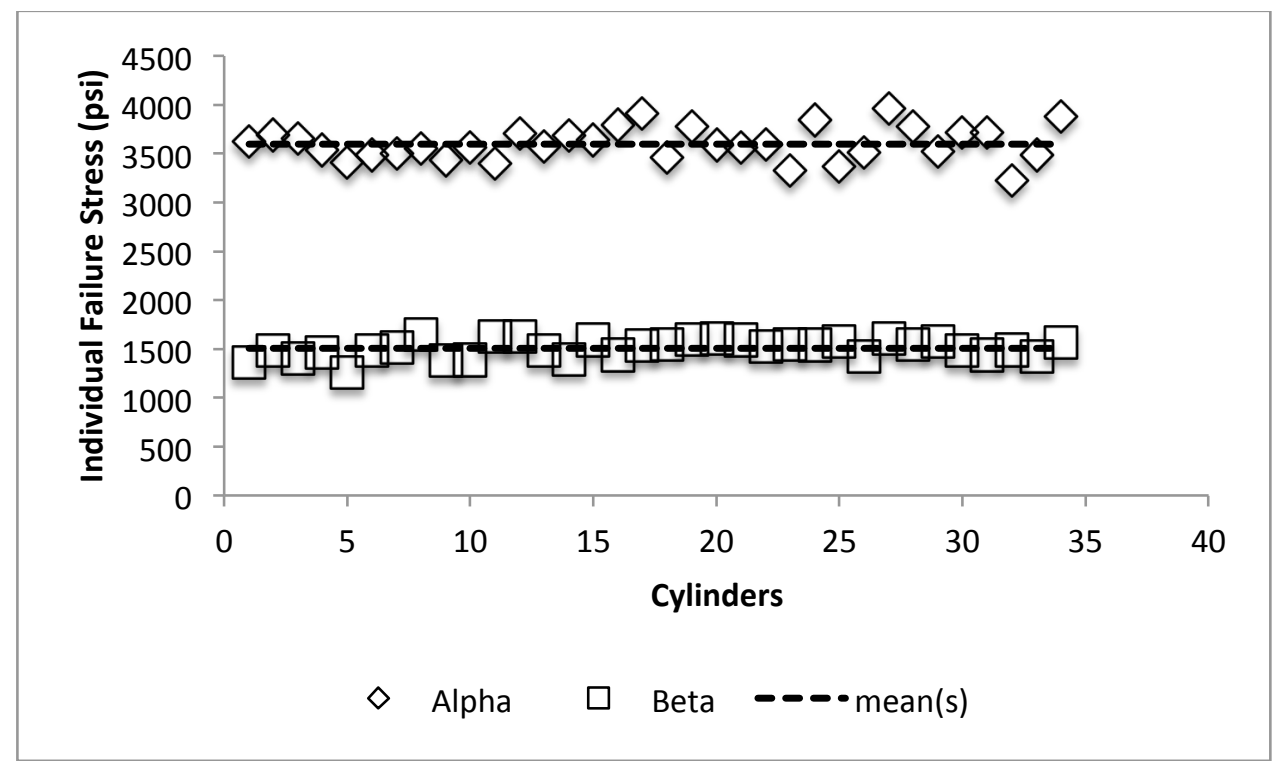

Figure 5: Variation in Individual Cylinder Failure Stress

The variation in individual cylinder unit weight was less than that of the failure stress (see Figure $6)$.

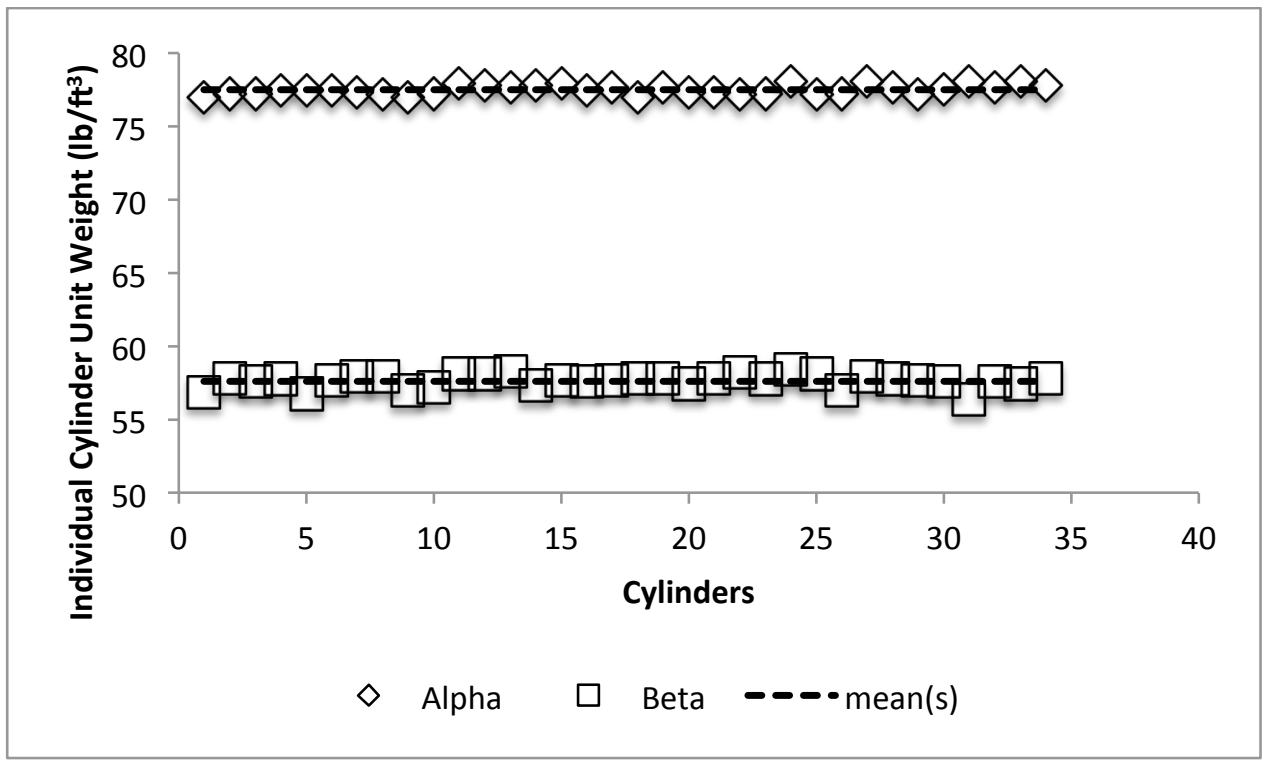

Figure 6: Variation in Individual Cylinder Unit Weight

With no obvious outliers, the last specimen tested was excluded from the test results, in accordance with ACI 214R-11, where three test specimen's equal one test (see Table 10 Appendix). The spread of both the unit weight and failures stress was limited, and the mean unit weight of both the Alpha \& Beta mix cylinders was slightly above their respective official unit weight of 77.17 vs. $77.5 \mathrm{lb} / \mathrm{ft}^{3}$ (Alpha) and $56.63 \mathrm{vs.} 57.6 \mathrm{lb} / \mathrm{ft}^{3}$ (Beta). 


\subsection{ACTUAL VS BATCHED VALUES}

The slump values for each mix were within the planned range of between $5 \& 6$ in, with 5.25 in for Alpha and 6in for Beta (see Table 6). There were a number of deviations from the planned proportions due to a number of factors (see Table 11 in the appendix). For the Alpha mix the planned water content was too high to achieve the planned slump. In order to achieve the desired slump, an additional $13.23 \mathrm{lb}$ of cement was added $(+18.4 \%$ difference $)$, in order to reach a slump of $5.25 \mathrm{in}$. For the Beta mix the opposite problem was encountered, not enough slump. To rectify this, an additional $8.21 \mathrm{lb}$ of water was added $(+31.9 \%$ difference $)$ to reach a slump of 6in. There was some difference in the bulk volumes of Poraver batched in both mixes, due to measurement device limitations. However there was significant difference in the mass of Poraver batched across all five sizes and both mixes, with differences of between 6.4$19.5 \%$ recorded.

The bulk volumes obtained from the Poraver storage bags changed with each mix, with a difference between mixes of $0-26 \%$ and $1-18 \%$ from the manufacturers supplied values. The bulk unit weights obtained were compared to the Poraver given values (see Table 7).

Table 7: Poraver Batched Bulk Unit Weights

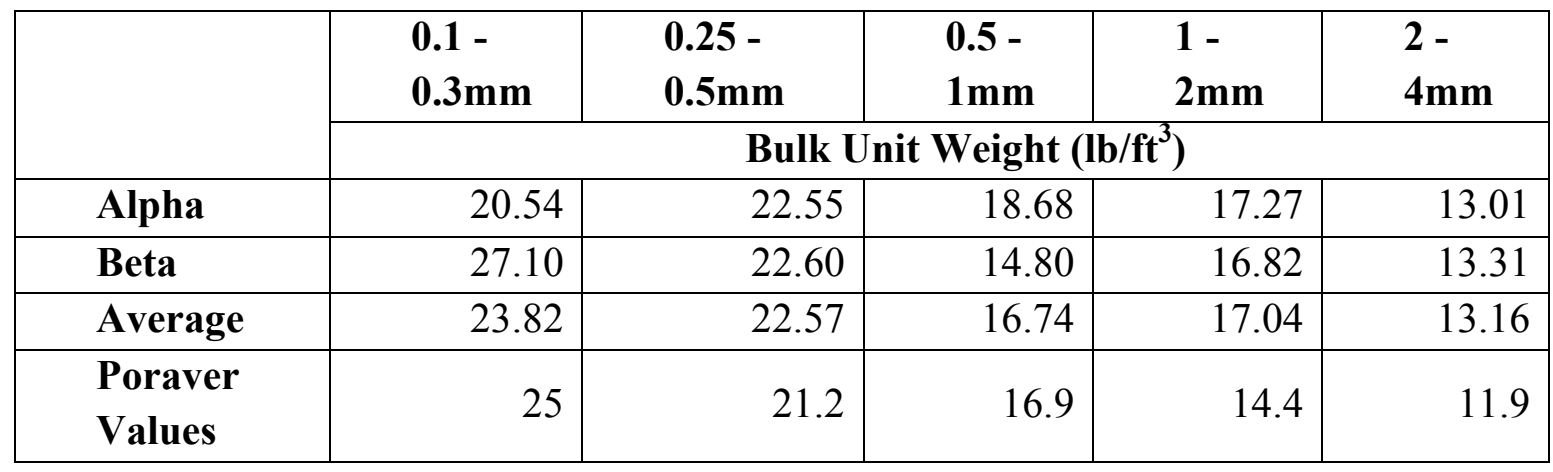

\subsection{Comparison With Pilot Study}

A comparison of the first and second stages Unit Weight vs. Failure stress was completed to determine if they are from the same population (see Figure 7). 


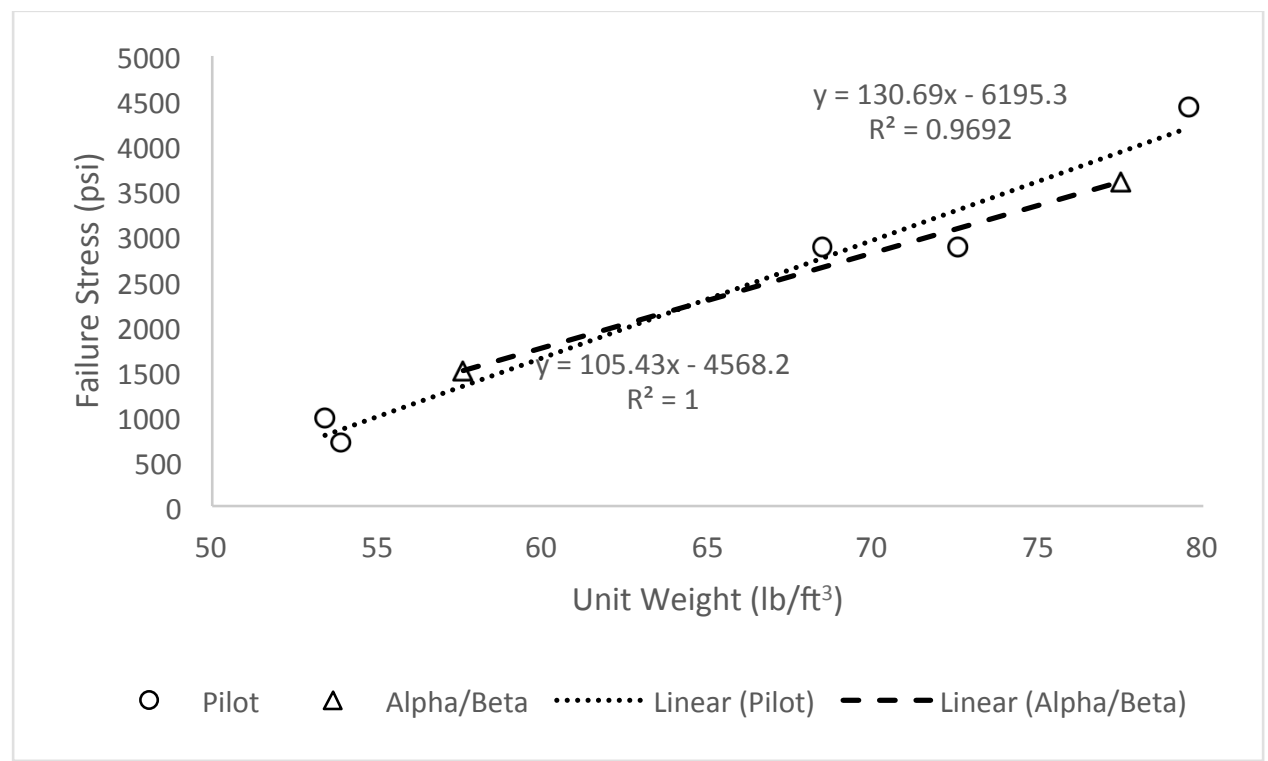

Figure 7: Population Analysis

\subsection{ACI CHARTS}

ACI211.2-98 Figure 3.2 \& ACI211.2-98 Figure 3.3 were reproduced including both the stage $1 \& 2$ data (see Figure 8 \& Figure 9).

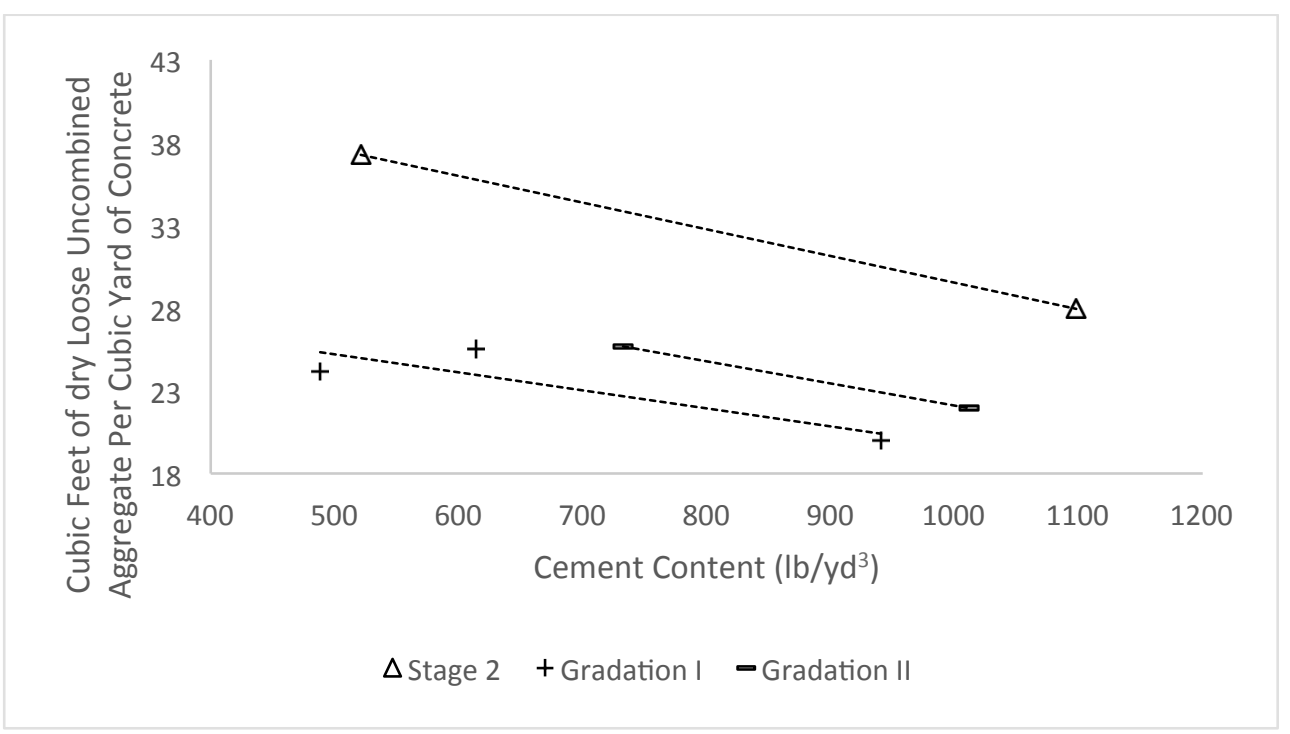

Figure 8: Design Chart for Uncombined Aggregates for Poraver-Based Lightweight Concrete 


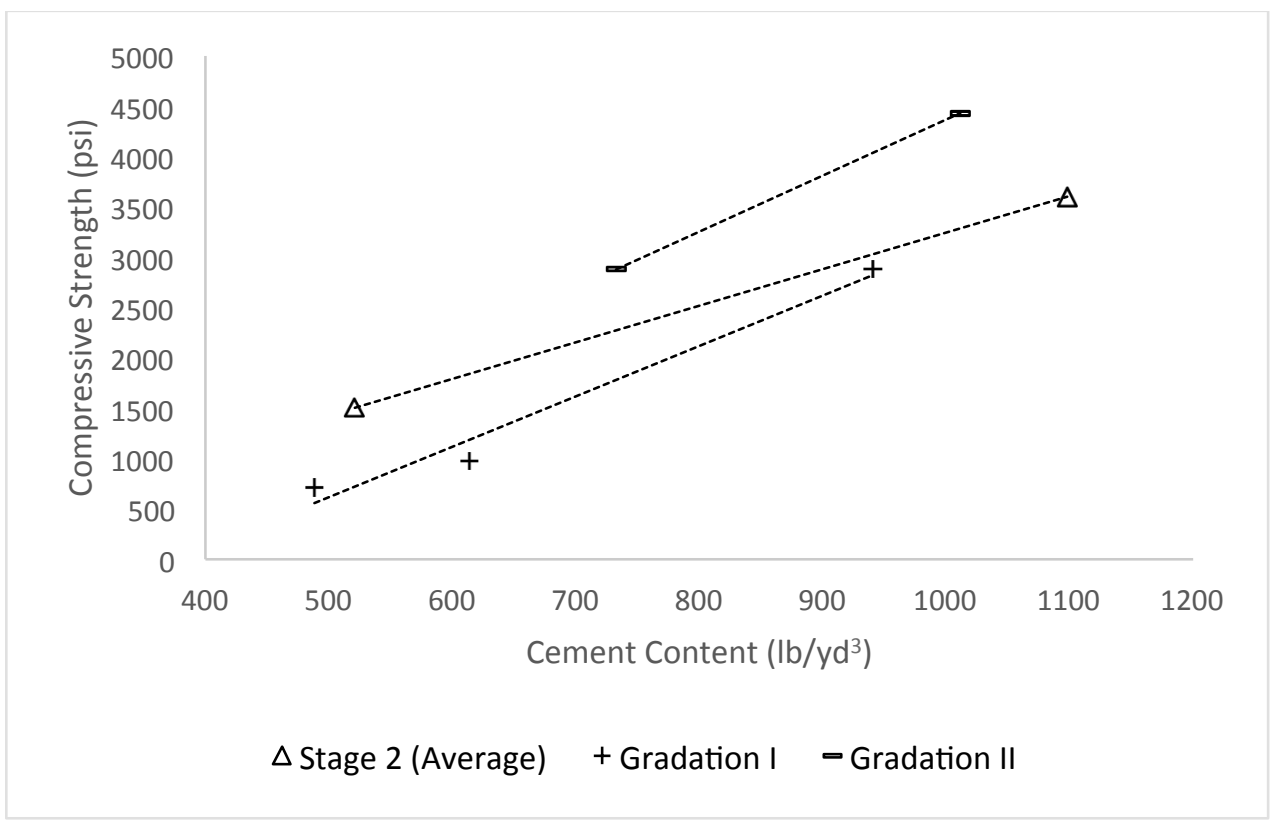

Figure 9: Strength vs. Cement Content

\subsection{Supplemental Design ChaRT}

A non ACI Chart of Failure Stress as a function of Unit Weight was developed to aid in the batching process. For comparative purposes the unit weight of water is given as a horizontal line. The chart shows that with the Stage 2 data, the maximum failure stress possible from a mix with a unit weight less than water is approximately 2000 psi (see Figure 10).

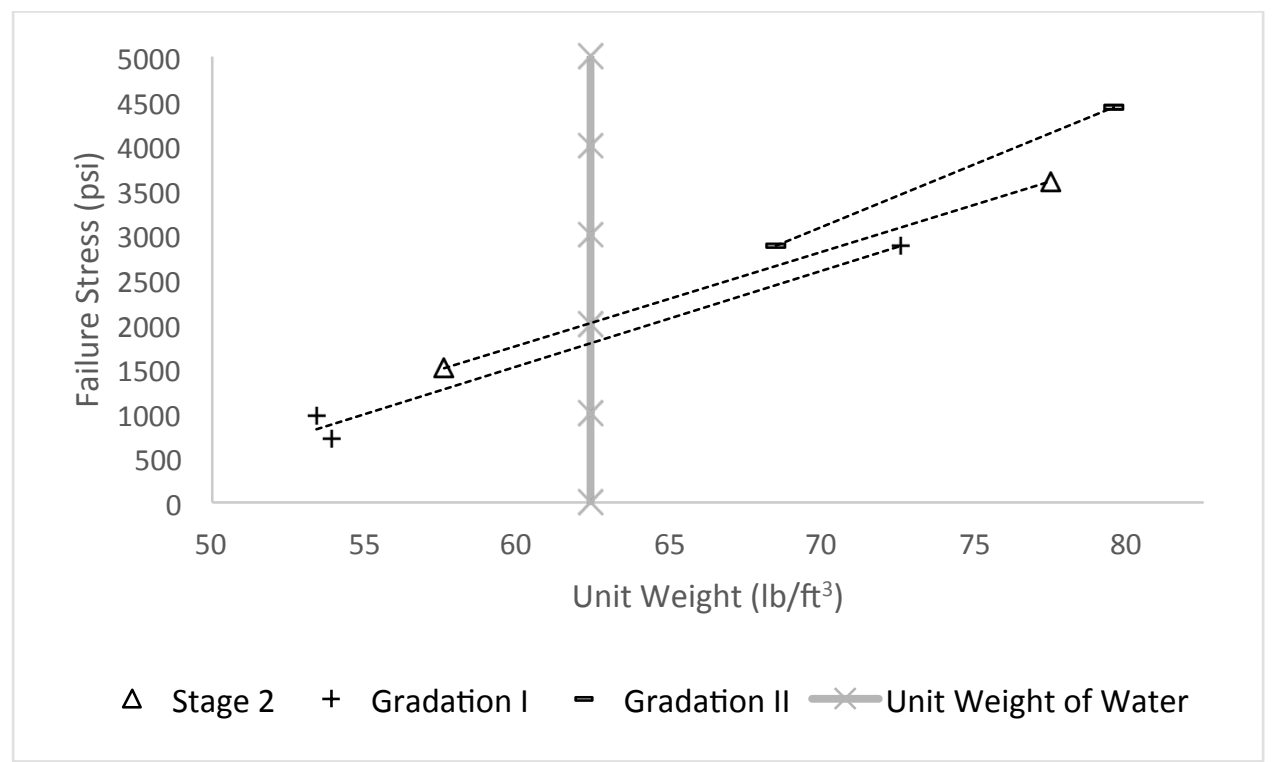

Figure 10: Failure Stress as a Function of Unit Weight 


\subsection{Cylinder FAILURE TyPE}

According to ASTM C39, there are 6 main concrete cylinder failure types (see Figure 11). Type 1 (cones) is generally the most common, however Type's 5 (side fracture) \& 6 (pointed side fracture) are common with unbonded caps, as was the case in this study.

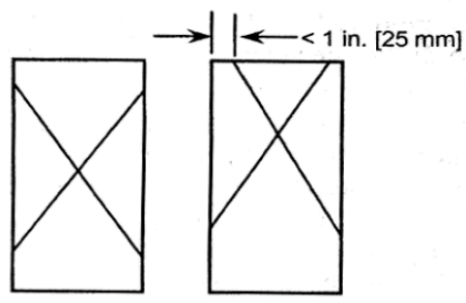

Type 1

Reasonably well-formed cones on both ends, less than 1 in. [ $25 \mathrm{~mm}$ ] of cracking through caps

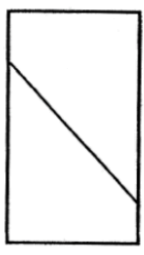

Type 4

Diagonal fracture with no cracking through ends; tap with hammer to distinguish from Type 1
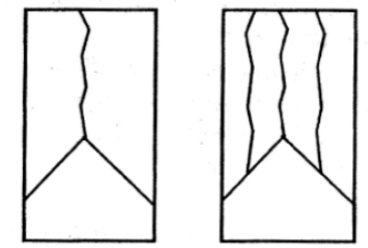

Type 2

Well-formed cone on one end, vertical cracks running through caps, no welldefined cone on other end
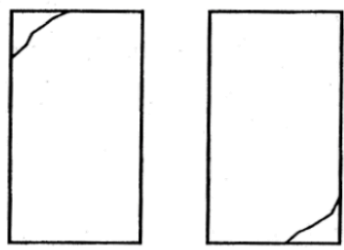

Type 5

Side fractures at top or bottom (occur commonly with unbonded caps)

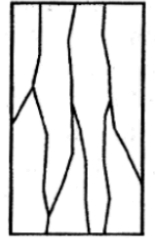

Type 3

Columnar vertical cracking through both ends, no well-

formed cones

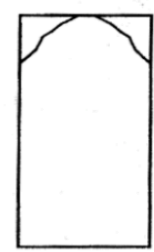

Type 6

Similar to Type 5 but end of cylinder is pointed

Figure 11: Cylinder Failure Types 9 (ASTM C39)

For stage 2, only Types 3-6 were found, with Type 6 occurring most frequently (see Table 8). 
Table 8: Frequency of ASTM C39 Cylinder Failure Types

\begin{tabular}{|r|l|r|r|}
\hline \multicolumn{2}{|l|}{} & Alpha & Beta \\
\hline Type & Description & \multicolumn{2}{|c|}{ Frequency } \\
\hline $\mathbf{1}$ & $\begin{array}{l}\text { Reasonably well-formed cones on both ends, less } \\
\text { than 1in. (25mm) of cracking through caps }\end{array}$ & 0 & 0 \\
\hline & $\begin{array}{l}\text { Well-formed cone on one end, vertical cracks } \\
\text { running through caps, no well-defined cone on } \\
\text { other end }\end{array}$ & 0 & 0 \\
\hline $\mathbf{3}$ & $\begin{array}{l}\text { Columnar vertical cracking through both ends, } \\
\text { no well-formed cones }\end{array}$ & 4 & 6 \\
\hline $\mathbf{4}$ & $\begin{array}{l}\text { Diagonal fracture with no cracking through } \\
\text { ends; tap with hammer to distinguish from type 1 }\end{array}$ & 1 & 3 \\
\hline $\mathbf{5}$ & $\begin{array}{l}\text { Side fracture at top or bottom (occur commonly } \\
\text { with unbonded caps) }\end{array}$ & 11 & 6 \\
\hline $\mathbf{6}$ & Similar to Type 5 but end of cylinder is pointed & 18 & 19 \\
\hline & $\quad$ Total & 34 & 34 \\
\hline
\end{tabular}

An analysis was performed to determine if there was any relationship between failure stress and failure type (see Figure 12).

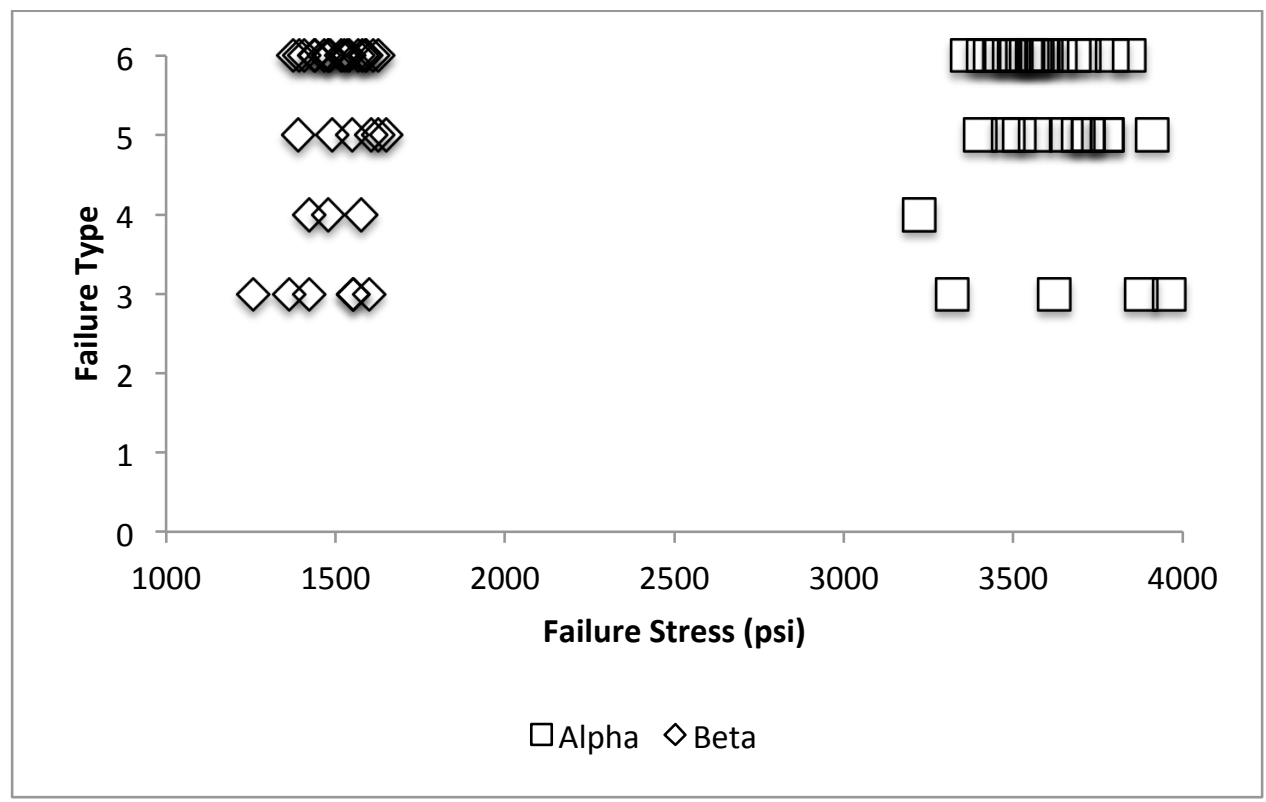

Figure 12: ASTM C39 Failure Type vs. Failure Stress

For examples of failure types found see Figure 13 (Type 3), Figure 14 (Type 4), Figure 15 (Type 5) \& Figure 16 (Type 6). 


\subsection{Strength, Aggregate FaCtor \& Unit Weight as a FunCtion OF CEMENT Content}

Informative values for Stage 2 of the study were derived using linear regressions of the data. The range of values shown, include values that are not realistic, but are included for comparative purposes. The practical limits of cement content using this gradation is between $250-2836 \mathrm{lb} / \mathrm{yd}^{3}$, this provides a range of strengths possible from 520-9919 psi (see Table 9).

Table 9: Strength, Aggregate Factor \& Unit Weight as functions of Cement Content

\begin{tabular}{|c|c|c|c|}
\hline Cement (C) & Strength $(\mathrm{S})^{4}$ & Aggregate factor (AF) ${ }^{5}$ & Unit Weight $(\gamma)^{6}$ \\
\hline $\mathrm{lb} / \mathrm{yd}^{3}$ & psi & $\mathbf{f t}^{3} / \mathbf{y d} \mathbf{d}^{3}$ & $\mathbf{l b} / \mathbf{f t}^{3}$ \\
\hline 0 & -389 & 45.7 & 39.6 \\
\hline 107 & 0 & 43.9 & 43.3 \\
\hline 250 & 520 & 41.6 & 48.3 \\
\hline 382 & 1000 & 39.5 & 52.8 \\
\hline 500 & 1428 & 37.6 & 56.9 \\
\hline $521^{\mathrm{a}}$ & 1505 & 37.3 & 57.6 \\
\hline $660^{\mathrm{b}}$ & 2009 & 35.0 & 62.4 \\
\hline 750 & 2337 & 33.6 & 65.5 \\
\hline 1000 & 3246 & 29.6 & 74.1 \\
\hline $1098^{\mathrm{a}}$ & 3602 & 28.0 & 77.5 \\
\hline 1250 & 4154 & 25.5 & 82.8 \\
\hline 1500 & 5063 & 21.5 & 91.4 \\
\hline 1750 & 5972 & 17.5 & 100.0 \\
\hline 2000 & 6880 & 13.5 & 108.6 \\
\hline 2500 & 8697 & 5.4 & 125.9 \\
\hline 2836 & 9919 & 0.0 & 137.5 \\
\hline
\end{tabular}

\footnotetext{
${ }^{4} \mathrm{~S}=3.6345 \mathrm{C}-388.77$

${ }^{5} \mathrm{AF}=-0.0161 \mathrm{C}+45.66$

${ }^{6} \gamma=0.0345 \mathrm{C}+39.64$
} 


\subsection{Discussion}

A discussion of the eight main areas of findings is presented below, this includes: Gradation, Slump, Water-Cement Ratio, Unit Weight, Air/Error, ACI Charts, Failure Types and Handing.

\subsection{Gradation}

One of the key characteristics of concrete is the ability to modify the mixture design with numerous parameters. The first and one of the most fundamental, is the aggregate gradation. The gradation can be modified in numerous ways, from changing the range of sizes used, adjusting the nominal maximum aggregate size, and modifying distribution of the sizes selected. The gradation selected or developed will have a significant impact on the resulting concrete. As can be seen from the pilot study in Figure $4 \&$ Table 3, reducing the nominal maximum aggregate size will increase both the strength and unit weight. Within a single gradation there is a range of values of strength and weight possible, which can be seen in Figure $9 \&$ Figure 10. Within any specific gradation there is a practical limit to the strength range possible, for Stage 2 this limit approaches 8697 psi, with a very small aggregate factor of $5.4 \mathrm{ft}^{3} / \mathrm{yd}^{3}$ which results in a unit weight of $125.9 \mathrm{lb} / \mathrm{ft}^{3}$ similar to that of normal weight concrete, see Table 9.

\subsection{SLUMP}

Following ACI211.2-98, slump for Stage 2 of this study was set within the range of 5-6 in. The two trial batches, Alpha (5.25 in) \& Beta (6 in) fell near the outer limits of this range. There is a nonlinear relationship with mixing water and slump, adding additional water has an increasing effect on water content, strength and unit weight. Had the slump of Alpha and Beta been identical, it is likely that there would be a reduced strength difference.

\subsection{WATER-CEMENT RATIO}

For this study two different water-cement ratios have been reported, Total W/C (WCT) and W/C Excluding Absorbed Water (WCX). Both of these values are useful, the WCX is the mixing water required for a given slump, and WCT is the potential total water available for hydration. For the Alpha mix the WCT was 0.52 and WCX 0.44, these values are similar to typical normal weight concrete values, and could be significantly reduced by decreasing the slump. The values for the Beta mix of WCT of 0.97 and WCX 0.76 however are significantly above normal values. One possible explanation for the high $\mathrm{WC}$ values for the Beta mix is the increased surface area. Poraver aggregates are smaller than commonly used aggregates, and therefore the total surface area of the aggregate is higher. The Beta mix had 33.6\% more aggregate by weight, but $52.5 \%$ less cement by weight, than the Alpha mix. Surface area and weight has a linear relationship, therefore it is reasonable for the Beta mix to require $41.7 \%$ more water to spread the reduced cement over the increased surface area of the Poraver. This relatively high water-cement ratio is not necessarily a negative parameter. With the Beta 
mixes' strength of 1500 psi and unit weight of $57.6 \mathrm{lb} / \mathrm{ft}^{3}$ it could be a strong candidate for structural fill applications. The total water contents of $486 \mathrm{lb} / \mathrm{yd}^{3}$ (Alpha) \& $395 \mathrm{lb} / \mathrm{yd}^{3}$ (Beta) compares well to the expected value of $472 \mathrm{lb} / \mathrm{yd}^{3}$, determined from expanding on the approximate values of expected water content from Figure 21: ACI211.2-98 Table 3.2 (See Appendix B).

\subsection{UNIT WEIGHT}

For normal weight concrete, the unit weight of the resultant mix is generally not a determinative constraint. For lightweight concrete, the design may require a specific unit weight or acceptable range. Unit weight will be heavily influenced by both the choice of aggregate and the gradation of the aggregate. Due to the relationship between unit weight and strength, a compromise will be required to fit both parameters. For Poraver with the gradation used, 4000 psi concrete can be obtained with a unit weight of $81.3 \mathrm{lb} / \mathrm{ft}^{3}$, and $5000 \mathrm{psi}$ with a unit weight of $90.8 \mathrm{lb} / \mathrm{ft}^{3}$ (see Table 9).

\subsection{AIR/ERROR}

In order to accurately test the air content of lightweight concrete, a volumetric air meter or Roll-A-Meter is required, according to ASTM C173. This method uses isopropyl alcohol and water to separate the air from the concrete mix. An air meter that requires pressure to determine air content cannot be used with lightweight concrete because the reading will likely be in excess of the actual air content. Most lightweight aggregates are very porous in nature and it is recommended they be presoaked before batching to allow for internal curing and to maintain the available mixing water during batching. The additional pressure (above atmospheric) of a traditional air meter could force additional water into the pores of the aggregate increasing the reported air content, above the actual air content.

For this study, the appropriate air meters were not available, and consequently the air content could not be accurately measured. Instead a value of "air/error" has been reported. This value includes both the air content of the batches, as well as the total error made during batching. It is not possible to determine how much of that value is from error, or air, and either parameter could influence the percentage. Expanding on the approximate values of expected entrapped air from Figure 21: ACI211.2-98 Table 3.2 (See Appendix B), provides an expected air content of approximately $4.43 \%$. The reported values of $3.5 \%$ (Alpha) \& 5.3\% (Beta), comparatively appear reasonable for air content alone and can be used as placeholders until more accurate data is available. 


\subsection{ACI CHARTS}

Design charts where produced following the requirements of ACI211-2-98. The first, Figure 8 shows the linear relationship between cement content and aggregate bulk volume. This figure is very similar to the ACI211.2-98 Figure 3. A wider distribution in the aggregate factor range

of $28-37 \mathrm{ft}^{3} / \mathrm{yd}^{3}$ was found, compared to the ACI's expected range of $28-34 \mathrm{ft}^{3} / \mathrm{yd}^{3}$. This wider range could be accounted for in the difference in the size of the aggregates, the ACI chart uses 19.0-4.75mm aggregate compared, to this study which uses $4.0-0.1 \mathrm{~mm}$. This difference seems reasonable as the bottom of the range $\left(28 \mathrm{ft}^{3} / \mathrm{yd}^{3}\right)$ is identical and the upper bound is merely $8 \%$ higher. The second, Figure 9 show the linear relationship between compressive strength and cement content. This figure is very similar to ACI211.2-98 Figure 3 (see Appendix B). The slope of the line was approximately $1 / 3$ that of the ACI, this could be explained by the difference in aggregates compressive strength, with Poraver being the weaker alternative, or different cement type, and admixtures used in the ACI values. Due to the limited scope of this study, a 1000 psi range of strength outcomes was not possible; however using the data from the pilot study and Stage 2 an approximate range becomes apparent, similar to that of the ACI. The strength values reported in this study were $1 / 2-1 / 3$ lower in magnitude for a given cement content than the ACI. Again this could be explained by the aggregate choice, or because unbonded caps were used in this study.

\subsection{FAILURE TYPES}

One limitation of this study that likely impacted the results was the decision to use unbonded caps when testing the cylinders. Bonding the caps would have increased the reliability and precision of the results and likely would have led to higher failure stresses. From observations of the tests it was apparent that due to the stress concentrations and potential eccentricity, there was premature failure of a number of cylinders. When using bonded caps, Type 1 failure is most common for normal weight concrete. Failure types are generally used to show outliers and can help to explain lower than expected results. For this study, Type $5 \& 6$ failures were most prevalent, with no Type 1 or 2 failures observed. The use of bonded caps could have altered the results and more Type 1 failures may have occurred. There were however no significant outlying cylinders, which limits the usefulness of the failure type specification. It is likely that had bonded caps been used the failure stresses of the test cylinders would have been higher, and the distribution of the failure type more typical. Had this been the case there may also have been outliers that could have been identified using failure type. 


\subsection{HaNdLing}

A significant aspect of uncertainty and potential error in this study originated with the bulk volumes of the aggregates. As the Poraver was batched, the unit weights generally increased toward to bottom of the storage packages. This is indicative of settling of the Poraver during transportation and storage. For higher quality control, the Poraver should be sieved and the unit weight of each grain size determined.

The following changes are made to the pilot study recommendations (Section 2.1.4.1):

B1: In addition, measure and record the dry mass of Poraver. This can be used to adjust the mix if the unit weights vary from the expected values.

B2: Soaking water should be in excess of absorption requirements, but well below estimated total water requirements. It is recommend the water added to the Poraver for soaking should be absorbed water plus $50 \%$ of mixing water. This should eliminate "over watering" the concrete mix, if the estimated mixing water is excessive.

T1: Motor oil was an ineffective form release; it did not preventing cylinders from sticking to the base of the forms. Investigate more effective form release agents 


\subsection{CONCLUSION}

Poraver-based lightweight concrete has desirable qualities for a number of applications. This study has highlighted the available strengths and unit weights from a single sample gradation. With the use of more advanced techniques, admixtures and additional pozzolanic compounds, Poraverbased concrete has the potential to be used in a variety of high strength applications.

\subsection{GUIDELINES FOR PORAVER-BASEd LWC}

Poraver-based concrete can effectively be batched following the ACI211.2-98 Volumetric method. In general, Poraver-based lightweight concrete has a useful range of strengths that can meet and exceed ACI213R-14 requirements for structural concrete of 3-5000 psi. ACI211.2-98 defines LWC as concrete with a unit weight no greater than $115 \mathrm{lb} / \mathrm{ft}^{3}$, Poraver-based concrete can easily exceed these specifications, with unit weights of as little as $57.6 \mathrm{lb} / \mathrm{ft}^{3}$ shown, with less theoretically possible. There is a lot of extra strength capacity available with decreased slump, use of admixes and use of supplementary cementitious material such as fly ash or silica fume. Additionally the unit weight of Poraver-based concrete can be reduced by the above techniques and by modifications to the aggregate gradation.

\subsubsection{Handling Poraver}

Poraver is difficult to measure wet, it is recommended to only attempt to measure its weight and volume in a dry state. Additionally there will be inconsistency in the unit weight of the stockpiled Poraver. It may be necessary to determine the average unit weight of the stockpile before determining the proportions of the concrete mixture.

\subsubsection{Cement Range}

With Poraver-based concrete each additional $250 \mathrm{lb} / \mathrm{yd}^{3}$ will yield approximately an additional 1000 psi of compressive strength. For structural fill applications where unit weight is the priority, it is recommended to start with test mixtures with cement contents in the range of $500-1000 \mathrm{lb} / \mathrm{yd}^{3}$. For structural applications test mixes in the range of 1000 $1000 \mathrm{lb} / \mathrm{yd}^{3}$ would be applicable.

\subsubsection{How To Use This Report To Develop Mix Designs}

For applications where low unit weight is important, Poraver-based LWC should be a option considered. Section 3.6, provides an initial starting point for determining the range of values available. After determining if Poraver-based LWC is a good fit for the project, Sections $3.3 \& 3.4$ provide initial starting point for aggregate volume and cement content. Once initial mix designs have been established, Sections 2.1.4.1 \& 4.8 can be used in conjunction with ASTM standards and ACI codes to finalize the batching procedure. Section 5.2 provides a look at the limitations of this study and presents areas further research that may be applicable. 


\subsection{LiMITATIONS \& RECOMMENDATIONS}

One of the key advantages of concrete as a building material is the almost infinite ability to modify the mixture proportions to achieve desired outcomes. Due to the nature of concrete proportioning it is difficult to hold all variables constant, excluding one, and compare outcomes. This study briefly looked at two gradations, across three cement contents in the Pilot study. For Stage 2, only a single gradation with two cement contents was tested. Due to the limitations and findings of this study there are numerous areas for further research.

One potential significant limitations of this study was the use of non-bonded caps on the test specimens. It is likely that higher strengths would have been observed with caps, and a tighter strength distribution would have been recorded.

The air content of the test batches was unable to be measured for this study. Without his data, the results are more limited and one control of the ACI211.2-98 Volumetric method was eliminated. Due to time and resource limitations cement contents, gradations and slumps were limited.

This study was limited to two cement contents of approximately $500 \& 1000 \mathrm{lb} / \mathrm{yd}^{3}$. The theoretical limits as shown in Table 9 are $250-2500 \mathrm{lb} / \mathrm{yd}^{3}$. It would be a valuable experiment to test these outer limits, to show the outer limits of strength and to gain experience working with such mixes.

The test specimens were all tested on the same day at the 28-day threshold. This limited the study to one temporal data point. Had time and resources allowed, additional specimens could have been tested over time and compared with non-presoaked specimens to determine the benefits of presoaking. Additionally, time for testing for tensile strength and the stress-strain relationship was not allowed for.

Presoaking lightweight and porous aggregates is necessary to allow for adequate hydration and predictable results. Presoaking also has the additional benefit of internal curing which can increase the concrete strength over time. For this study Poraver was soaked under atmospheric conditions for 24 hours before batching. It is assumed, but unclear if the Poraver absorbed the maximum quantity of water possible. It is also unclear what the ideal level of absorption is for presoaking aggregates. A further study could investigate different techniques of presoaking and mix and compare batches with differing levels and timelines of presoaking. This could include soaking the Poraver under additional pressure or extended time. The effect on strength, unit weight, and workability would be valuable. A study using a non-presoaked control mix, compared to a presoaked mix would be valuable in quantifying the additional benefits of presoaking. This study should test both mixes over a time period of at least one year to see the potential benefits of presoaking. This study would be helpful in determining if presoaking is 
always worth the extra effort involved, for both strength and workability. It may show that for low strength applications it is unnecessary. 


\section{REFERENCES}

American Concrete Institute (ACI). ACI 211.1-91, Selecting Proportions for Normal, Heavyweight and Mass Concrete. Farmington Hills: ACI, 2009.

American Concrete Institute (ACI). ACI 211.2-98, Selecting Proportions for Structural Lightweight Concrete. Farmington Hills: ACI, 1998.

American Concrete Institute (ACI). ACI 213R-14, Guide for Structural Lightweight-Aggregate Concrete. Farmington Hills: ACI, 2014.

American Concrete Institute (ACI). ACI 214R-11, Guide to Evaluation of Strength Test Results of Concrete. Farmington Hills: ACI, 2011.

American Concrete Institute (ACI). ACI 506R-05, Guide to Shotcrete. Farmington Hills: ACI, 2005.

ASTM C39 / C39M-16, Standard Test Method for Compressive Strength of Cylindrical Concrete Specimens, ASTM International, West Conshohocken, PA, 2016, www.astm.org

ASTM C138 / C138M-16, Standard Test Method for Density (Unit Weight), Yield, and Air Content (Gravimetric) of Concrete, ASTM International, West Conshohocken, PA, 2016, www.astm.org

ASTM C173 / C173M-16, Standard Test Method for Air Content of Freshly Mixed Concrete by the Volumetric Method, ASTM International, West Conshohocken, PA, 2016, www.astm.org

ASTM C192 / C192M-16, Standard Practice for Making and Curing Concrete Test Specimens in the Laboratory, ASTM International, West Conshohocken, PA, 2016, www.astm.org

ASTM C231 / C231M-14, Standard Test Method for Air Content of Freshly Mixed Concrete by the Pressure Method, ASTM International, West Conshohocken, PA, 2014, www.astm.org

Calkins, Meg. Materials for Sustainable Sites: A Complete Guide to the Evaluation, Selection, and Use of Sustainable Construction Materials. Hoboken, NJ: Wiley, 2009.

Cutler, Phillip. "Lightweight Aggregates: How Do You Make the Right Decision? The Short List..." National Precast Concrete Association. July 18, 2011. Accessed February 10, 2016. http://www.precast.org/. 
Forty, Adrian. Concrete and Culture: A Material History. London: Reaktion, 2012.

Kosmatka, Steven H., Beatrix Kerkhoff, and William C. Panarese. Design and Control of Concrete Mixtures. 14th ed. Skokie, Ill.: Portland Cement Association, 2008.

Mamlouk, Michael S., and John P. Zaniewski. Materials For Civil and Construction Engineers. Third ed. New Jersey: Prentice Hall, 2011.

Martin, David P., Alec S. Zimmer, Michael J. Bolduc, and Emily R. Hopps. "Is Lightweight Concrete All Wet?" STRUCTURE Magazine. January 2013. Accessed February 10, 2016. http://www.structuremag.org/.

Maruyama, Ippei, and Ai Sugie. "Numerical Study on Drying Shrinkage of Concrete Affected by Aggregate Size." Journal of Advanced Concrete Technology ACT 12, no. 8 (2014): 279-88.

Ozyildirim, Celik. "Influence of Aggregate Size on Concrete Strength and Shrinkage." Concrete International, August 1, 2015, 71-72.

Portland Cement Association. Special Concretes, Mortars and Products. New York, New York: John Wiley \& Sons, 1975.

Short, Andrew, and William Kinniburgh. Lightweight Concrete. 3rd ed. London: Applied Science Publishers, 1978.

Videla, Carlos, and Mauricio Lopez. "Mixture Proportioning Methodology for Structural SandLightweight Concrete." ACI Materials Journal MJ 97-M34 (2000): 284-86. Accessed September 21, 2015. 


\section{APPENDICES}

The following appendices are attached.

\section{A: RESEACH DATA}

A summary of the results of this study is included.

\section{B: ACI FIGURES}

ACI charts are included for comparative purposes. 


\section{APPENDIX A RESEARCH DATA}


Table 10: Summary of Test Data

\begin{tabular}{|c|c|c|c|c|}
\hline & \multicolumn{2}{|c|}{ Alpha } & \multicolumn{2}{|c|}{ Beta } \\
\hline & Unit Weight & Failure Stress & Unit Weight & Failure Stress \\
\hline Test & $\mathrm{lb} / \mathbf{f t}^{3} \mathbf{2 8 - d a y}$ & psi & $\mathrm{Ib} / \mathrm{ft}^{3} \mathbf{2 8 - d a y}$ & psi \\
\hline 1 & 77.2 & 3656 & 57.4 & 1416 \\
\hline 2 & 77.4 & 3478 & 57.4 & 1400 \\
\hline 3 & 77.2 & 3498 & 57.6 & 1514 \\
\hline 4 & 77.7 & 3559 & 57.8 & 1546 \\
\hline 5 & 77.8 & 3629 & 57.8 & 1487 \\
\hline 6 & 77.4 & 3721 & 57.7 & 1507 \\
\hline 7 & 77.5 & 3642 & 57.7 & 1598 \\
\hline 8 & 77.5 & 3587 & 58.1 & 1539 \\
\hline 9 & 77.5 & 3611 & 57.7 & 1537 \\
\hline 10 & 77.5 & 3671 & 57.7 & 1537 \\
\hline 11 & 77.9 & 3475 & 57.1 & 1451 \\
\hline Mean & 77.5 & 3594 & 57.6 & 1503 \\
\hline Median & 77.5 & 3611 & 57.7 & 1514 \\
\hline Standard Deviation & 0.241 & 82.4 & 0.260 & 59.8 \\
\hline Max & 77.9 & 3721 & 58.1 & 1598 \\
\hline Min & 77.2 & 3475 & 57.1 & 1400 \\
\hline
\end{tabular}


Table 11: Batched vs. Planned Values

\begin{tabular}{|c|c|c|c|c|c|}
\hline & \multicolumn{2}{|c|}{ Alpha } & \multicolumn{2}{|c|}{ Beta } \\
\hline & & $\begin{array}{l}\text { Mass } \\
\text { (lb) }\end{array}$ & $\begin{array}{c}\text { Bulk } \\
\text { volume }\left(\mathrm{ft}^{3}\right)\end{array}$ & $\begin{array}{l}\text { Mass } \\
\text { (lb) }\end{array}$ & $\begin{array}{c}\text { Bulk } \\
\text { volume }\left(\mathrm{ft}^{3}\right)\end{array}$ \\
\hline \multirow{3}{*}{ Cement } & Planned & 65.45 & - & 39.27 & - \\
\hline & Actual & 78.68 & - & 39.27 & - \\
\hline & $\%$ Difference & $18.36 \%$ & - & $0 \%$ & - \\
\hline \multirow{3}{*}{$\begin{array}{l}\text { Water- } \\
\text { hydration }\end{array}$} & Planned & 36.00 & - & 21.60 & - \\
\hline & Actual & 34.84 & - & 29.81 & - \\
\hline & \% Difference & $-3.27 \%$ & - & $31.94 \%$ & - \\
\hline \multirow{3}{*}{$0.1-0.3 \mathrm{~mm}$} & Planned & 2.46 & 0.10 & 3.57 & 0.14 \\
\hline & Actual & 2.02 & 0.10 & 3.87 & 0.14 \\
\hline & \% Difference & $-19.45 \%$ & $0.11 \%$ & $7.98 \%$ & $-0.20 \%$ \\
\hline \multirow{3}{*}{$0.25-0.5 \mathrm{~mm}$} & Planned & 3.69 & 0.17 & 5.36 & 0.25 \\
\hline & Actual & 3.98 & 0.18 & 5.71 & 0.25 \\
\hline & \% Difference & $7.60 \%$ & $1.41 \%$ & $6.40 \%$ & $0.00 \%$ \\
\hline \multirow{3}{*}{0.5 - 1mm } & Planned & 5.54 & 0.33 & 8.04 & 0.48 \\
\hline & Actual & 6.10 & 0.33 & 7.04 & 0.48 \\
\hline & \% Difference & $9.66 \%$ & $-0.28 \%$ & $-13.27 \%$ & $-0.02 \%$ \\
\hline \multirow{3}{*}{1 - $2 \mathrm{~mm}$} & Planned & 7.38 & 0.51 & 10.72 & 0.74 \\
\hline & Actual & 8.93 & 0.52 & 12.53 & 0.75 \\
\hline & \% Difference & $19.04 \%$ & $0.93 \%$ & $15.60 \%$ & $0.09 \%$ \\
\hline \multirow{3}{*}{$2-4 m m$} & Planned & 5.54 & 0.47 & 8.04 & 0.68 \\
\hline & Actual & 6.06 & 0.47 & 8.98 & 0.67 \\
\hline & \% Difference & $8.94 \%$ & $0.13 \%$ & $10.99 \%$ & $-0.18 \%$ \\
\hline
\end{tabular}




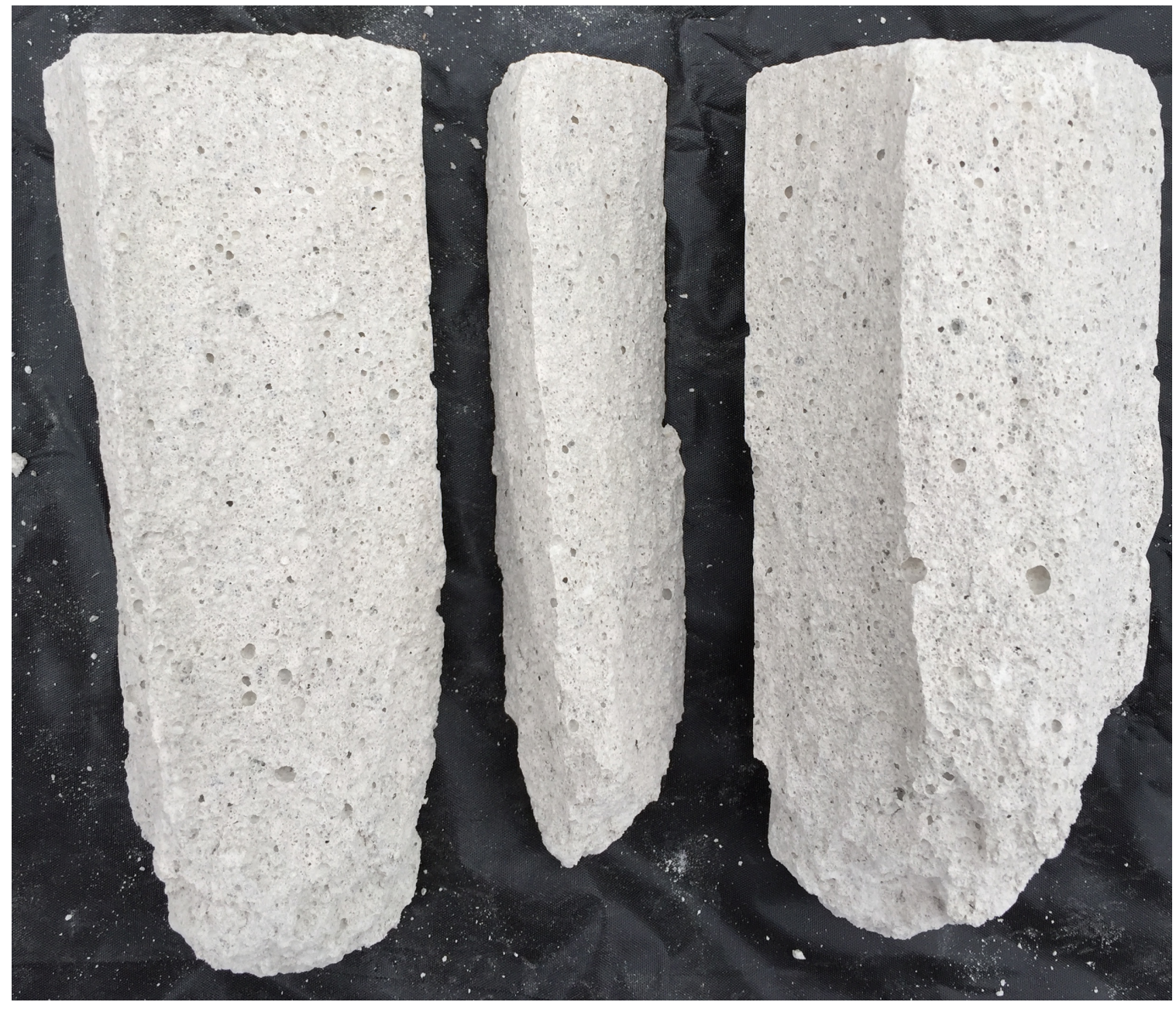

Figure 13: Type 3 Cylinder Failure 


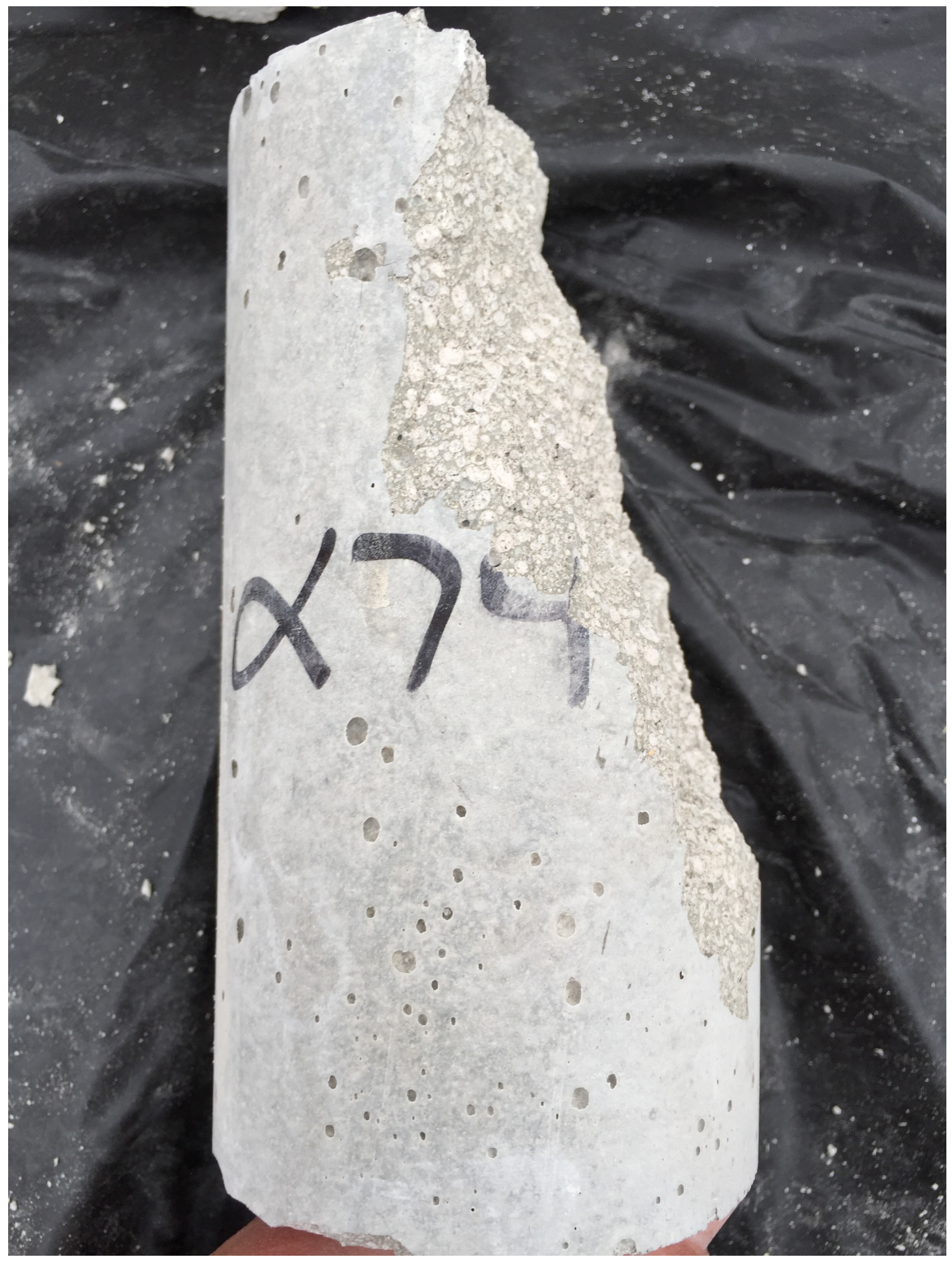

Figure 14: Type 4 Cylinder Failure 


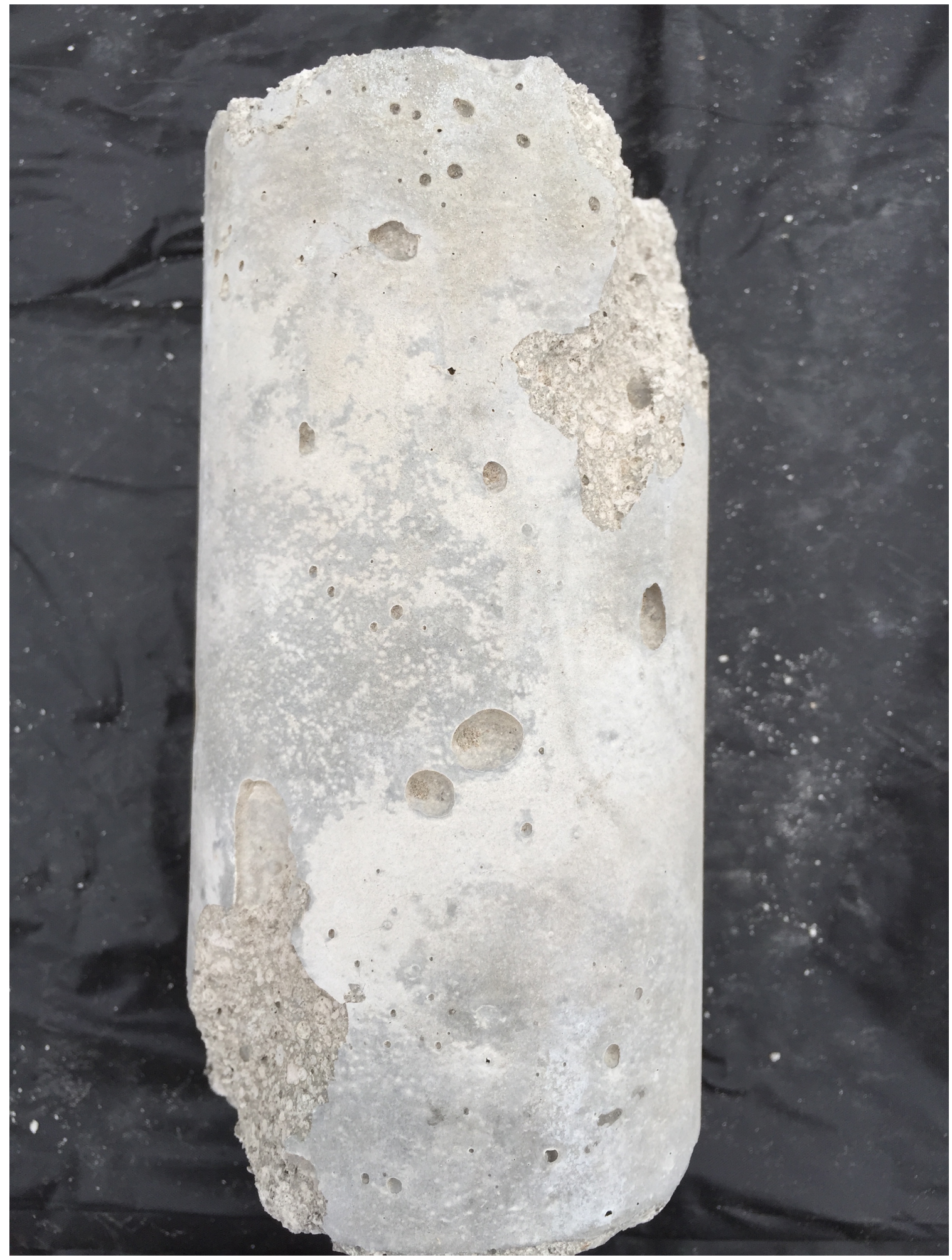

Figure 15: Type 5 Cylinder Failure 


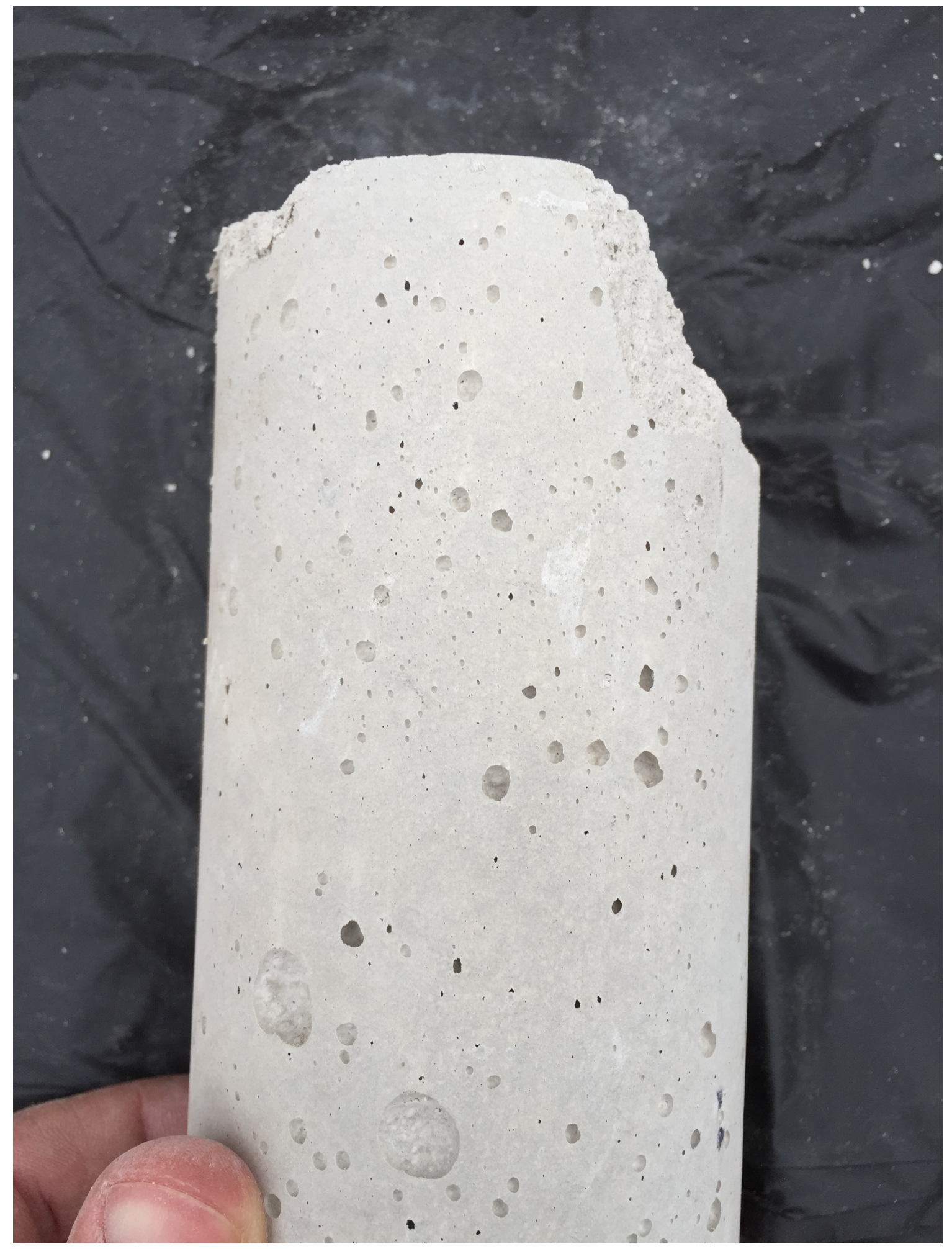

Figure 16: Type 6 Cylinder Failure 
$\frac{\text { APPENDIX B }}{\text { ACI FIGURES }}$ 


\begin{tabular}{|c|c|c|}
\hline \multirow{2}{*}{$\begin{array}{c}\text { Sieve size, U.S. } \\
\text { standard square mesh }\end{array}$} & \multicolumn{2}{|c|}{ Percent by weight passing individual sieves } \\
\hline & Grading No. 1 & Grading No. 2 \\
\hline $3 / 4$ in. $(19 \mathrm{~mm})$ & - & - \\
\hline $1 / 2$ in. $(12 \mathrm{~mm})$ & 一 & 100 \\
\hline $3 / 8$ in. $(10 \mathrm{~mm})$ & 100 & 90 to 100 \\
\hline No. $4(4.75 \mathrm{~mm})$ & 95 to 100 & 70 to 85 \\
\hline No. $8(2.4 \mathrm{~mm})$ & 80 to 98 & 50 to 70 \\
\hline No. $16(1.2 \mathrm{~mm})$ & 50 to 85 & 35 to 55 \\
\hline No. $30(600 \mu \mathrm{m})$ & 25 to 60 & 20 to 35 \\
\hline No. $50(300 \mu \mathrm{m})$ & 10 to 30 & 8 to 20 \\
\hline No. $100(150 \mu \mathrm{m})$ & 2 to 10 & 2 to 10 \\
\hline
\end{tabular}

Figure 17: ACI506R-05 Table1.1

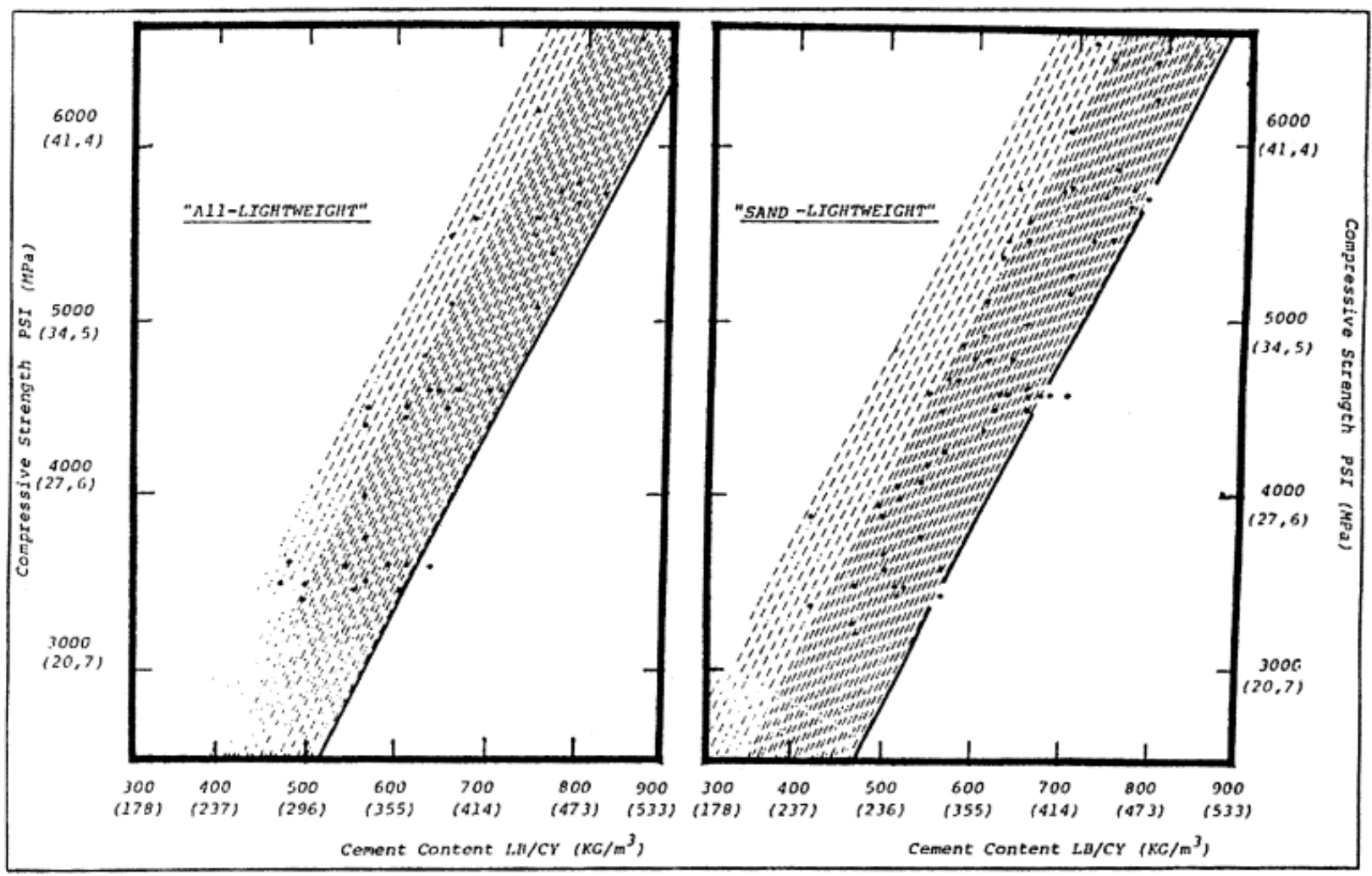

Figure 18: ACI211.2-98 Figure 3.1 
DESIGN CHART FOR UNCOMBINED AGGREGATES FOR LIGHTWEIGHT CONCRETE

ASTM C $3303 / 6$ in-No. 4 MATERIAL *

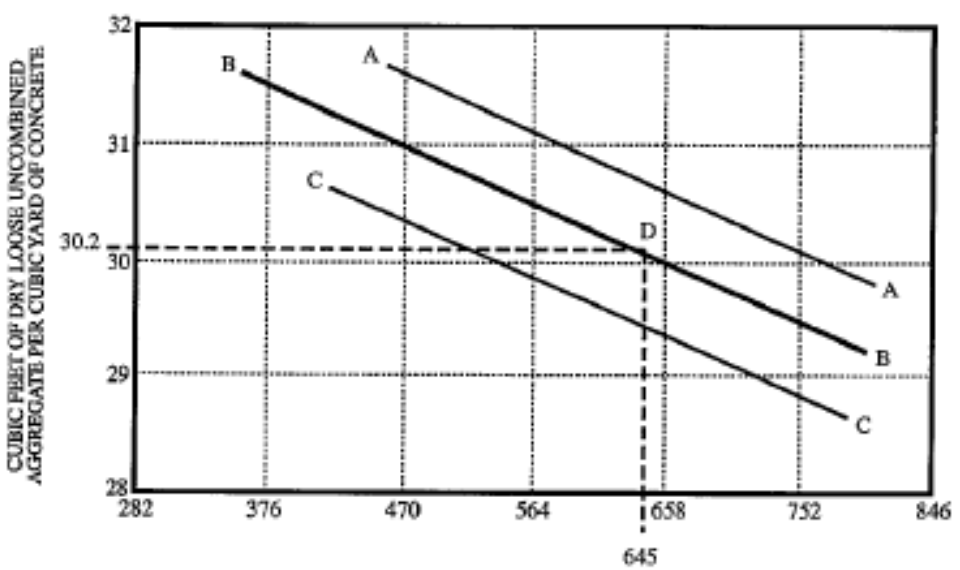

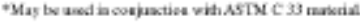

CEMENT CONTENT: Jb/yd

Figure 19: ACI211.2-98 Figure 3.2

STRENGTH VS CEMENT CONTENT

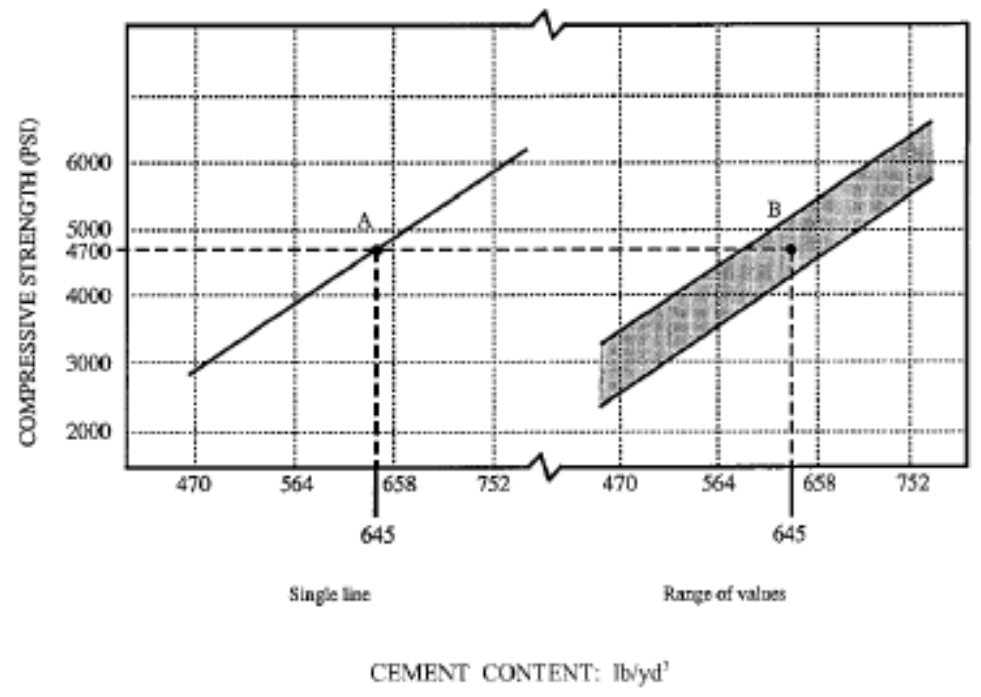

Figure 20: ACI211.2-98 Figure 3.3 


\begin{tabular}{|c|c|c|c|}
\hline \multirow[b]{2}{*}{ Slump, in. } & \multicolumn{3}{|c|}{$\begin{array}{l}\text { Water, } \mathrm{lb} / \mathrm{yd}^{3} \text { of concrete for indicated } \\
\text { nominal maximum sizes of aggregates }\end{array}$} \\
\hline & $3 / 8$ in. & $1 / 2$ in. & $3 / 4$ in. \\
\hline \multicolumn{4}{|c|}{ Air-entrained concrete } \\
\hline 1 to 2 & 305 & 295 & 280 \\
\hline 3 to 4 & 340 & 325 & 305 \\
\hline 5 to 6 & 355 & 335 & 315 \\
\hline \multicolumn{4}{|l|}{$\begin{array}{l}\text { Recommended average } \dagger \text { total air } \\
\text { content, percent, for level of } \\
\text { exposure }\end{array}$} \\
\hline Mild exposure & 4.5 & 4.0 & 4.0 \\
\hline Moderate exposure & 6.0 & 5.5 & 5.0 \\
\hline Extreme exposure ${ }^{t}$ & 7.5 & 7.0 & 6.0 \\
\hline \multicolumn{4}{|c|}{ Non-air-entrained concrete } \\
\hline 1 to 2 & 350 & 335 & 315 \\
\hline 3 to 4 & 385 & 365 & 340 \\
\hline 5 to 6 & 400 & 375 & 350 \\
\hline $\begin{array}{l}\text { Approximate amount of entrapped } \\
\text { air in non-air-entrained con- } \\
\text { crete, percent }\end{array}$ & 3 & 2.5 & 2 \\
\hline \multicolumn{4}{|c|}{$\begin{array}{l}\text { Quantities of mixing water given for air-entrained concrete are based on typical } \\
\text { total contents requirements as shown for "moderate exposure" in the table above. } \\
\text { These quantities of mixing water are for use in computing cement or cementitious } \\
\text { materials content for trial batches at } 68 \text { to } 77 \mathrm{~F} \text {. They are maximum for reasonably } \\
\text { well-shaped angular aggregates graded within limits of accepted specifications. The } \\
\text { use of water-reducing chemical admixtures (ASTM C } 494 \text { ) may also reduce mixing } \\
\text { water by } 5 \text { percent or more. The volume of the liquid admixtures is included as part } \\
\text { of the total volume of the mixing water. The slump values of } 7 \text { to } 11 \text { in. are only } \\
\text { obtained through the use of water-reducing chemical admixture; they are for concrete } \\
\text { containing nominal maximum size aggregate not longer than } 1 \text { in. } \\
\text { TAdditional recommendations for air content and necessary tolerances on air content } \\
\text { for control in the field are given in a number of ACI documents, including ACI } 201 \text {, } \\
345,318,301 \text {, and } 302 \text {. ASTM C } 94 \text { for ready-mixed concrete also gives air content } \\
\text { limits. The requirements in other documents may not always agree exactly, so in pro- } \\
\text { portioning concrete, consideration must be given to selecting an air content that will } \\
\text { meet the needs of the job and also meet the applicable specifications. } \\
\text { IThese values are based on the criteria that } 9 \text { percent air is needed in the mortar phase } \\
\text { of the concrete. If the mortar volume will be substantially different from that deter- } \\
\text { mined in this recommended practice, it may be desirable to calculate the needed air } \\
\text { content by taking } 9 \text { percent of the actual mortar value. }\end{array}$} \\
\hline
\end{tabular}

Figure 21: ACI211.2-98 Table 3.2 